\title{
The phonology and morphology of Romanian diphthongization ${ }^{1}$
}

IOANA CHITORAN

Abstract

A unified analysis of three Romanian vowel alternations is proposed in this paper. The alternations occur between mid and low vowels $(a-$ - ) and between mid vowels and diphthongs $(e-e a ; o-o a)$ in stressed position. Diphthongization is treated as vowel lowering under stress. Departing from previous analyses, all three alternations are shown to be part of the same process, both phonologically and morphologically conditioned. The surface distribution of vowels and diphthongs falls out from the interaction of two conflicting forces acting on the stressed vowel of the stem: the pressure on the vowel to lower under stress, and the pressure to rise in a metaphony process conditioned by the vowel of an inflectional suffix. The analysis relies on the interaction of markedness and faithfulness constraints. The latter include a constraint responsible for metaphony, defined as an instance of faithfulness between the vowel of the stem and that of the suffix. Besides allowing a unified treatment of all three alternations, this analysis also reveals the typological relation of Romanian to other languages whose stress systems are sensitive to vowel height. The morphological distribution of vowels and diphthongs is accounted for by morphologically specific instantiations of constraints outranking the general, phonological ones.

1. I wish to thank two anonymous Probus reviewers, one in particular for detailed comments on the morphological analysis. I also thank Bill Ham and Lindsay Whaley for comments on earlier versions of this paper, and Joe Pater for discussion.

Probus 14 (2002), 205-246

0921-4771/02/014-0205

(C)Walter de Gruyter 


\section{Introduction}

One of the most studied aspects of Romanian phonology involves the development and status of the diphthongs [ea] and [oa]. The two diphthongs have come to be regarded as the "phonological signatures" of Romanian. Historically, the diphthongs have developed from Latin stressed /e/ and /o/ in the context of an open vowel in the following syllable:

$$
\begin{array}{llll} 
& \text { Latin } & \text { Romanian } & \\
\text { é > éá / }-\mathrm{C}_{0}\{\partial, \mathrm{a}, \mathrm{o}\} & \text { SERA } & \text { seárə } & \text { 'evening' } \\
\text { ó > óá / _ } \mathrm{C}_{0}\{\partial, \mathrm{e}, \mathrm{a}, \mathrm{o}\} & \text { ROTA } & \text { róátə } & \text { "wheel' }
\end{array}
$$

A large body of literature is devoted to the historical development of the diphthongs from Latin (Iordan 1921; Rosetti 1958, 1976, 1981; Agard 1958, 1984; Vasiliu 1968; Ruhlen 1973; Sala 1976; Pardess 1990 among others). The synchronic status of the diphthongs, on the other hand, has been considerably less studied (Rosetti 1959; Martinet 1962; Vasiliu 1965, 1990; Lombard 1974; Golopentia-Eretescu 1967; Avram 1991). The accounts of diphthongization proposed in the synchronic studies are, for the most part, rooted in the historical analysis of this process, thus missing, I argue, a number of important phonological generalizations, as well as their relation to morphology.

In the present study I investigate the full complexity of the phonological and morphological behavior of the diphthongs [ea] and [oa] in the native vocabulary of Romanian. I depart from previous analyses, and I propose a different account for the diphthongs, relying crucially on two new elements. First, I show that the synchronic alternations between mid vowels and diphthongs can be best understood if treated as part of a broader process of mid and low vowel alternations in the phonology of Romanian. The alternations are the result of two conflicting forces acting on the stressed vowel of the stem. There is pressure on this vowel to lower under stress, and at the same time to rise in a process of metaphony, conditioned by the high or mid front vowel of an inflectional suffix. The diphthongs and the low vowel /a/ pattern together with respect to metaphony. All three are affected by it, and consequently surface as mid vowels in metaphony environments.

Second, a complete account of these alternations must crucially consider their morphological role, along with their phonological conditioning. The analysis I propose here accounts for all three types of vowel alternations that occur under stress: é - éá, ó - oá, á - á.

In my analysis I adopt a constraint-based approach, in the framework of Optimality Theory, henceforth OT (Prince and Smolensky 1993; McCarthy and Prince 1995). The vowel alternations and the distribution of the diphthongs are accounted for by the interaction of two constraint families: the family of Faithfulness constraints conflicting with the $*$ Peak family of Markedness constraints 
(Kenstowicz 1994). The ranking of IDENT and *Peak constraints accounts for the surface occurrence of the diphthongs under stress, except in metaphony environments. I treat diphthongization as vowel lowering under stress, motivated by a preference for sonorous vowels in syllables which are prosodic heads. This preference is attested in a number of languages (see Kenstowicz 1994). The analysis I propose thus also situates Romanian typologically in relation to other languages whose stress systems are sensitive to vowel height (sonority).

Several interesting theoretical issues arise from the analysis. One concerns the typology of phonological systems with respect to the interaction of vowel height and stress. I argue that there are essentially four types of languages, and that all four can be predicted by the different rankings of a limited number of constraints. Romanian is therefore a linguistic system corresponding to one of the rankings. In capturing this fact, an OT analysis is seen to offer an advantage over a procedural account.

Secondly, I treat metaphony as a subcase of Faithfulness. The IDENT family is extended to include a match-up between the prominent vowel of the stem and the vowel of an inflectional suffix with respect to height. This presupposes that a correspondence relation holds between stem and affix, but it still remains to be seen how it fits in with other better studied cases of correspondence (inputoutput, base-reduplicant, output-output in morphologically related forms). This is a theoretical question which I mention, but I do not attempt to answer in this paper.

Another important issue is morphologization. I argue that Romanian has evolved from a stage where diphthongization was purely phonologically conditioned, to the current stage, where the phonological constraints active in the language have become morphologically restricted. To account for the morphological distribution of the diphthongs I rely on morphologically specific constraints, inspired by the lexically specific constraints proposed by Itô and Mester (1999), Pater (2000) among others.

I begin by presenting the relevant data in Section 2. In Section 3 I propose a representation of the diphthongs in terms of syllable structure. In Section 4 I outline the historical and traditional synchronic analyses of the diphthongs. I also discuss in some detail the interaction between vowel height and stress. In Section 5 I explain the phonological conditioning of the vowel alternations, and I propose an analysis for two types of metaphony which conflict with the pressure on mid vowels to lower under stress, thus blocking diphthongization in certain environments. In Section 6 I discuss the morphological role of the vowel alternations, and I propose an analysis of the morphologically conditioned alternations. Section 7 contains the conclusions of the study. 


\section{Data}

The phonemic vowel system that I assume for Romanian is given below:

$$
\begin{array}{ccc}
\mathrm{i} & \mathrm{i} & \mathrm{u} \\
\mathrm{e} & \mathrm{\partial} & \mathrm{o} \\
\text { ena } & \mathrm{a} & \text { oa }
\end{array}
$$

The commonly assumed inventory is a seven-vowel system that does not include the diphthongs. The only previous proposal for a square vowel system was made by Graur and Rosetti (1938). However, this insight was not discussed any further in the literature, and no attempt was made to explain the diphthongs based on this vowel inventory.

For the purposes of this study I will assume a set of vowel features relying on multiple aperture particles (cf. Schane 1984, 1995; Goad 1992; Parkinson 1996), which can easily capture stepwise shifts in vowel height. The surface inventory of Romanian vowels, including the diphthongs, is repeated below, with its feature composition based on Schane's (1995) Particle Phonology, which is well suited for representing diphthongization and monophthongization:

\begin{tabular}{|l|ccc|ccc|ccc|}
\hline Vowels & i & i & u & ə & e & o & a & eca & oa \\
\hline Particles & - & i & u & a & a & a & a & a & a \\
& & & & & i & u & a & a & a \\
& & & & & & & & i & u \\
\hline
\end{tabular}

In Schane's feature system, lil and lul are tonality particles, equivalent to the traits of palatality and labiality. lal is an aperture particle which captures the height (or openness) dimension. Degrees of vowel height are thus characterized by the number of aperture particles. In Romanian, which has three degrees of height, /a/ and the diphthongs pattern together as having two aperture particles.

Stress in Romanian falls on the rightmost syllable of the prosodic word. The prosodic word includes the root and derivational material, excluding inflections and desinence vowels. Thus, the penult is stressed when the final syllable contains the desinence vowel (4a), and the final syllable is stressed in the absence of a desinence vowel (4b). The same generalization holds for morphologically derived words (4c), except that in this case the rightmost syllable of the prosodic word is part of the derivational suffix:

$$
\begin{array}{lll}
\text { a. } & \text { kəmá } \left.\int\right]_{P W} e & \text { 'shirt' } \\
\text { b. } & \text { kastrón] } & \text { 'bowl' } \\
\text { c. } & \text { kəməf-úts }]_{P W} \text { ə } & \text { 'shirt' (diminutive) } \\
& \text { kastron-él] }]_{P W} & \text { 'bowl' (diminutive) }
\end{array}
$$


Romanian also contains a lexically marked stress pattern, with penultimate stress, illustrated in $(5 \mathrm{a}-\mathrm{c})$. Morphologically derived forms continue to follow the unmarked pattern, with stress on the suffix. ${ }^{2}$

$$
\begin{aligned}
& \text { a. kámer }]_{P W} \text { ə 'room' } \\
& \text { b. bivol] }]_{P W} \text { 'buffalo' } \\
& \text { c. kəmər-úts }]_{P W} \text { ə 'room' (diminutive) }
\end{aligned}
$$

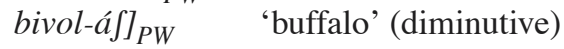

The data I introduce in this section illustrate the complexity of the mid voweldiphthong alternations in Romanian. There are systematic patterns of diphthongization under stress, exhibiting a behavior parallel to that of mid-low vowel alternations. In (6a, b, c), for example, we see that low vowels surface under stress, while mid vowels surface in unstressed position:
a. $ә-$
kárte
'book' kərt-it fik
(diminutive)
vákə 'cow' vək-útsə
(diminutive)
kásə 'house' kəs-útsə
(diminutive)
b. e-eá
'drunk' bets-iv
'drinker'
sếra
'evening'
in-ser-át
'dusk'
c. o- oá
poártว
koástə
'gate'
port-ár
'gatekeeper'
'rib'
kost-itsa
(diminutive)

This is a fairly common vowel reduction pattern, attested in many languages, including other Romance languages (e.g., Hualde 1992 for Catalan; Wetzels 1991 for Brazilian Portuguese). The focus of this study, however, is a second

\begin{tabular}{|c|c|c|c|c|}
\hline \multirow{4}{*}{ a. } & & Singular & Plural & \\
\hline & á -á & kárte & $k^{\prime} r r^{j}{ }^{j}$ & ‘book’ \\
\hline & á -á & brád & $b r a ́ z^{j}$ & 'fir tree' \\
\hline & & kásə & kás-e & 'house' \\
\hline \multirow[t]{5}{*}{ b. } & ẹá-é & beát & béts $^{j}$ & 'drunk' (m) \\
\hline & & bếátว & bét-e & 'drunk' (f) \\
\hline & & sênárə & sér $^{j}$ & 'evening' \\
\hline & & trếábə & tréb-ur ${ }^{j}$ & 'task' \\
\hline & ená - ená & flênák & $\begin{array}{l}\text { fleák- } \\
u^{j}{ }^{j}\end{array}$ & 'trifle' \\
\hline \multirow[t]{3}{*}{ c. } & oá - ó & poártə & pórts $^{j}$ & 'gate' \\
\hline & & noápte & nópts $^{j}$ & 'night' \\
\hline & oá - oá & koasto & koást-e & 'rib' \\
\hline
\end{tabular}
set of alternations, where both mid and low vowels are found under stress.

2. Constraint interaction for stress will not be discussed here. For a full analysis see Chitoran (2001). 
The connection between the different alternations in (7) has not previously been made in the literature. In the data above, we see a tendency for the stressed vowel to be low. The systematicity of the diphthongs' distribution has led to the common exclusion of the diphthongs from the phonemic inventory of Romanian. Indeed, the diphthongs never surface in unstressed position. The data are further complicated by the fact that the language does contain (near) minimal pairs which suggest that the diphthongs should be considered phonemic.

$\begin{array}{llll}\text { teámə } & \text { 'fear' } & \text { témə } & \text { 'theme' } \\ \text { seár } & \text { 'evening' } & \text { sérə } & \text { 'greenhouse' } \\ \text { toánə } & \text { 'whim' } & \text { tónə } & \text { 'ton' } \\ \text { koápsə } & \text { 'hip' } & \text { kóbzə } & \text { old musical instrument }\end{array}$

Moreover, we will see that the diphthongs are also morphologized. This is most evident in verb paradigms, for example, where they occur in some of the forms of the present tense indicative and subjunctive, depending on the conjugation class of the verb:
a. pleká (1 conj.)
'to go'
Singular
Plural
b. dormí (4 conj.) 'to sleep'
1 plék$$
2 \text { plét }^{j}
$$$$
\begin{array}{lll}
3 & \text { pleákə } & \text { pleákə } \\
1 & \text { dórm } & \text { dormím }
\end{array}
$$

The analysis I propose will account for both the phonological and the morphological aspects of the behavior of the diphthongs. To begin with, in the next section I propose a phonological representation for the diphthongs, and I provide a number of arguments to support it.

\section{The representation of diphthongs}

Three possible representations can be proposed for the diphthongs, in terms of their moraic structure: one in which the glide belongs to the onset (10a), one in which the glide belongs to the nucleus, and shares a mora with the following vowel (10b), and one in which the glide and the vowel belong to a bimoraic nucleus (10c). 


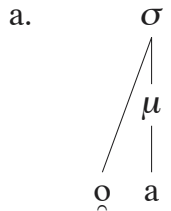

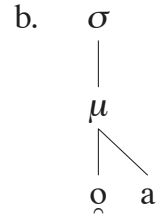

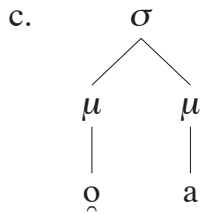

The three representations make different predictions. The first one predicts that either the onset or the nucleus part of the sequence may separately participate in alternations. According to (10b) the sequence is predicted to always function as a single unit. The prediction made by (10c) is that syllables containing [e्n] or [oa] have extra weight. I argue for (10b) as the correct representation, and I present below a number of arguments which support this claim.

One observation which argues against (10a) is that in most of the forms containing diphthongs, [ea] and [oa] alternate morphologically with the mid vowels [e] and [o], respectively.

$\begin{array}{rllll}\text { sg. } & \text { óáste } & \text { pl. } & \text { óft } t^{j} & \text { 'army' } \\ \text { sg. } & \text { noápte } & \text { pl. } & \text { nópts }{ }^{j} & \text { 'night' } \\ \text { sg. } & \text { séárə } & \text { pl. } & \text { sér }{ }^{j} & \text { 'evening' } \\ \text { fem. sg. } & \text { néágrə } & \text { masc. sg. } & \text { négru } & \text { 'black' }\end{array}$

Based on this alternation, I propose that the representation of the diphthong parallels that of a monophthongal vowel, such that both elements of the diphthong share a syllable nucleus, rather than being split between onset and nucleus.

An argument specifically in support of (10b) comes from a distinction between diphthongs and glide-vowel sequences, similar to the one found in French (Morin 1976; Kaye and Lowenstamm 1984; Tranel 1992; Rialland 1994). It has been argued for French, based on this distinction, that diphthongs share a syllable nucleus, while glides occur in non-nuclear positions (onset and coda). A well-formed onset in French, as in Romanian, consists of two elements, or a maximum of three, the first of the three being a sibilant. The argument brought up as evidence for French syllable structure is the rule of glide formation, which syllabifies a high vowel as a glide when followed by another vowel. Glide formation applies when the onset contains only one segment as in (12a), but it will not take place if the onset contains two segments, such as an obstruent (O) and a liquid (L), as in (12b).

French

a. Simple onsets; glide formation

$\begin{array}{lll}\text { lier } & \text { 'to bind', } & {[\text { lje } \sim \text { lije }]} \\ \text { nier } & \text { 'to deny' } & {[\text { nje } \sim \text { nije }]} \\ \text { il y a } & \text { 'there is' } & {[\text { ilja } \sim \text { ilija } \sim \text { ja }]} \\ \text { nouer } & \text { 'to tie' } & {[\text { nwe } \sim \text { nue }]}\end{array}$


b. Complex onsets (OL); no glide formation (*OLG)

$\begin{array}{lll}\text { plier 'to fold' } & {[\text { plije }]} & * \text { plje } \\ \text { clouer 'to nail down' } & {[\text { kluwe }]} & * \text { klwe }\end{array}$

Based on the blocked glide formation in OL onsets, the following OLGV syllables that do surface in French have been explained by treating the glidevowel portion as a diphthong contained in the nucleus, rather than as a glidevowel sequence. Thus, the following sequences constitute diphthongal nuclei:

$$
\begin{array}{llll}
\boldsymbol{w a} & \text { trois } & \text { 'three' } & {\left[t_{\text {Bw }}\right]} \\
\boldsymbol{\varphi} \boldsymbol{i} & \text { truite } & \text { 'trout' } & {\left[t_{\text {B }} \text { it }\right]} \\
w \tilde{\varepsilon} & \text { groin } & \text { 'muzzle' } & {\left[g_{B} w \tilde{\varepsilon}\right]}
\end{array}
$$

Kaye and Lowenstamm (1984) proposed two different representations for glides and diphthongs, in terms of their position in the syllable structure:

a.

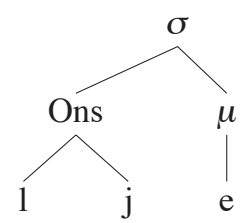

b. Diphthongs

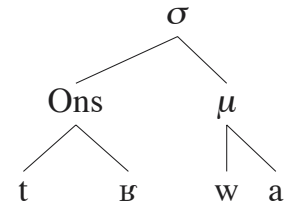

A similar distinction can be found in Romanian syllable onsets. The diphthongs [ea] and [oa] can be preceded by obstruent-liquid clusters (15a), but a glidevowel sequence cannot (15b).

\begin{tabular}{|c|c|}
\hline broás.kə & 'frog' \\
\hline ploá.je & 'rain' \\
\hline dreá.gə & 'to mend' \\
\hline proás.pət & ‘fresh’ \\
\hline pleá.kə & 'he leaves' \\
\hline freá.kə & 'rubs' \\
\hline treá.bə & 'task' \\
\hline
\end{tabular}

Romanian

a. Complex onsets (diphthongs)

b. No complex onsets (glides)

$\begin{array}{lll}\text { bri.jófə } & \text { 'roll' } & * \text { brjo } \\ \text { kli.jént } & \text { 'customer' } & * \text { klje } \\ \text { dri.jádə } & \text { 'dryad' } & * \text { drja } \\ \text { pri.jéten } & \text { 'friend' } & * \text { prje } \\ \text { pli.jánt } & \text { 'folder' } & * \text { plja }\end{array}$


These data support the syllable structure proposed in (10b), where [ea] and [oa] constitute diphthongal syllable nuclei.

Finally, the representation in (10c) implies that the diphthongs are bimoraic. It is true that they occur only in stressed syllables, but these syllables can be either open or closed. In the case of closed syllables, if the diphthongs are bimoraic, and if the coda consonant also bears a mora, then the resulting syllable would be trimoraic. There is no evidence from the phonological behavior of Romanian syllables to support the existence of three degrees of weight. Even if we assume that the coda consonant does not have a mora, and the resulting syllable is bimoraic, this would still predict a difference between diphthongal and monophthongal nuclei, for which there is no independent evidence.

Similar arguments are brought by Harris (1983) in support of the monomoraic representation of rising diphthongs in Spanish. Rising diphthongs, but not falling diphthongs, can occur in closed syllables in Spanish:

$$
\begin{array}{lll}
\text { Spanish (Harris 1983) } & & \\
\text { mwer. to 'dead' } & \text { krwel. dad } & \text { 'cruelty' } \\
\text { kljen.te 'customer' } & \text { trjun.fo } & \text { 'triumph' }
\end{array}
$$

I have presented here a number of arguments in favor of the representation in (10b), with diphthongs sharing a syllable nucleus. This representation best captures the phonological facts, notably that the diphthongs function as a single unit and a single segment in the types of alternations illustrated in (11).

I now turn to the representation of the featural composition of the diphthongs. I introduced in Section 1 the vowel inventory of Romanian, assuming Schane's $(1984,1995)$ particle model. In this system, the diphthongs consist of one tonality particle (lil or lul), and two aperture lal particles. Bearing in mind the evidence for the diphthongs' monomoraicity, I propose the following complete representation:
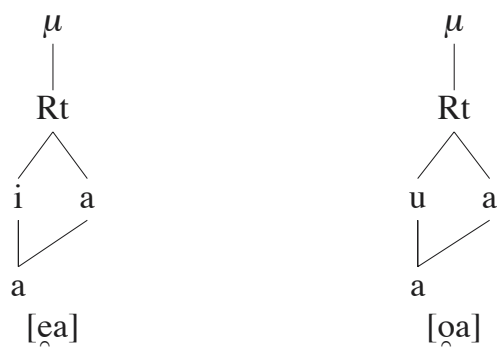

Example (17) differs in one respect from Schane's representation. It represents the diphthongs as consisting of only one root node. For Schane, diphthongs differ in the number of morae (the rising ones are monomoraic, and the falling ones are bimoraic), but they all consist of two root nodes, which distinguishes 
them from monophthongal vowels. I argue, however, that this is not the only possible way to capture this distinction, and that one-root node diphthongs should not be disallowed. I argue that the two-root node representation makes a prediction that is not borne out in all linguistic systems. It predicts that the two elements of a diphthong, corresponding to each root node, should exhibit independent phonological behavior. Such behavior is never observed in the Romanian diphthongs. The only existing alternations are those between diphthongs and monophthongal vowels, illustrated in (11). The representation I propose best captures the "contour" structure of a diphthong as a single segment.

In a one-root node structure the contrast between diphthongs and monophthongs can be represented as one between a split and an unsplit root node. This is the representation I adopt here. The particles lil and lal of the monophthong /e/ split below the root node level, and the additional lal particle of the resulting diphthong is represented as doubly linked to its two elements.

By splitting the particles below the root node, diphthongs violate INTEGRITY (McCarthy and Prince 1995: 372), the constraint which prohibits breaking an element.

INTEGRITY (McCarthy and Prince 1995)

"No element of S1 has multiple correspondents in S2."

Having established the structure of the diphthongs, I now turn to the final piece of background information: the historical development of the diphthongs and their traditional synchronic analysis in a rule-based system.

\section{Diachronic and traditional synchronic analyses}

Following Vasiliu (1968), the evolution of the Classical Latin vowel system to that of Balkan Romance and then to Common Romanian consists of three main changes which affect mid vowels. In Balkan Romance contrastive vowel length is lost, and the mid vowels /e/ and /o/ lower to / $/ \varepsilon /$ and $/ \mathrm{J} /$ under stress, resulting in a system with four degrees of height. At the next stage, in Common Romanian, the low mids / $/ \varepsilon /$ and / $/$ diphthongize to /ea/ and /oa/, respectively. Vasiliu proposes the following historical diphthongization rule:

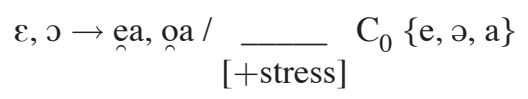

The development from Latin to Common Romanian is schematized below: 
(20)

\begin{tabular}{|c|c|c|c|c|}
\hline Latin & & Balkan Romance & & Common Romanian \\
\hline & & $\mathrm{e}, \mathrm{o} \quad \varepsilon, \rho$ & & $\mathrm{e}, \mathrm{o} \quad \mathrm{ea}, \mathrm{oa}$ \\
\hline $\begin{array}{l}V_{2} \\
\text { e }\end{array}$ & $\rightarrow$ & under stress & $\rightarrow$ & $\begin{array}{l}\text { under stress, } \\
\text { morphologized }\end{array}$ \\
\hline
\end{tabular}

In traditional synchronic analyses, which rely heavily on the historical one, the diphthongs are treated as being derived by a metaphony rule which diphthongizes a mid vowel under stress, preceding /a/ or /e/ in the following syllable:

$$
\begin{aligned}
& \mathrm{e} \rightarrow \text { ena } /[\overline{[+ \text { stress }]} \text { ə } \\
& \mathrm{o} \rightarrow \text { oa } / \overline{[+ \text { stress }]} \text { ə, e }
\end{aligned}
$$

To account for the $2-$ a alternation, a separate rule (22) is proposed by Golopentia-Eretescu (1967). She points out, however, that the rule is not phonological

\begin{tabular}{|c|c|c|c|c|}
\hline \multirow{7}{*}{ a. } & á $\rightarrow$ á /十 & {$[+$ stress $]$.} & \multicolumn{2}{|c|}{ (+=morpheme boundary) } \\
\hline & Feminine & Singular & Plural $\left({ }^{j}\right.$ or $\left.-u^{j}{ }^{j}\right)$ & \\
\hline & nouns & máre & $m \partial ́ r^{j}$ & ‘sea' \\
\hline & & vále & váj & ‘valley' \\
\hline & & báltə & bə́lts ${ }^{j}$ & 'puddle' \\
\hline & & mətáse & $m t^{\prime} s u{ }^{j}$ & ‘silk’ \\
\hline & & blánə & blónur $^{j}$ & ‘fur' \\
\hline b. & Masculine & Singular & Plural $\left({ }^{j}\right)$ & \\
\hline & nouns & brád & bráz ${ }^{j}$ & 'fir tree' \\
\hline & & kál & káj & 'horse' \\
\hline & & sák & sát $\int^{j}$ & ‘sack’ \\
\hline & Neuter & Singular & Plural (-ur ${ }^{\mathrm{j}}$ ) & \\
\hline & nouns & párk & párkur $^{j}$ & ‘park’ \\
\hline & & vál & válur $^{j}$ & ‘wave' \\
\hline
\end{tabular}
since it is restricted to feminine nouns. This morphological restriction is illustrated in (22).

(cf. Golopenţia-Eretescu 1967)

In the account I propose, the surface occurrence of the diphthongs and of [a] under stress is related to prominence, and the diphthongs are treated as low vowels arising from the lowering of mid vowels. However, I also show that synchronic diphthongization (vowel lowering) is not an exclusively phonological process, as the traditional rule implies. Although the historical diphthongization rule is a phonological rule, synchronically this view cannot be maintained, since the surface occurrence of diphthongs is both phonologically and morphologically 
conditioned. In the next two sections I propose an analysis of the phonological and morphological behavior of the diphthongs.

\section{Phonological conditioning of mid-low vowel alternations}

\subsection{The phonological behavior of ea and oa}

I focus in this section on the phonological component of the alternations. We will see that the two diphthongs do not have a perfectly parallel distribution. They both occur exclusively in stressed syllables, but there are, for example, fewer phonological restrictions on the occurrence of the diphthong /oa/. There is only one, in fact: the diphthong /oa/ never occurs in the final syllable of a prosodic word. As a consequence of this restriction, there are no monosyllabic words containing /oa/..$^{3}$

This generalization has to do with the gender of nouns. Monosyllabic forms happen to be mostly masculine forms, since the majority of them lack a desinence vowel that would add an extra syllable. Feminine words, on the other hand, always surface with the desinence vowel -ə or -e. Compare for example the masculine and feminine forms of the following nouns and adjectives, and the distribution of /o/ and /oa/:

\begin{tabular}{|c|c|c|c|}
\hline \multicolumn{2}{|c|}{ Masculine (ó) } & \multicolumn{2}{|c|}{ Feminine (oá) } \\
\hline domn & 'gentleman' & dоатпә & 'lady' \\
\hline hots & 'thief' & hoatsə & 'thief' f. \\
\hline orb & 'blind' & ôarbə & 'blind' f. \\
\hline gol & 'empty' & goalo & 'empty'f. \\
\hline frumos & ‘beautiful’ & frumoasə & 'beautiful' f \\
\hline
\end{tabular}

The diphthong /ea/ has two phonological restrictions. It is subject to two types of metaphony, both triggered by the vowel of an inflectional suffix, regardless of the number of intervening vowels. As a result of both types of metaphony, /ea/ never surfaces in plural forms, and /e/ surfaces instead.

\footnotetext{
3. Among recent French loanwords there are forms such as voal 'veil', trotuar 'sidewalk', anuar 'phone-book', culoar 'hallway' (here in orthography). The vocalic sequences in such forms are best treated as glide-vowel sequences rather than diphthongs. The mixed orthography (either $u$ or $o$ ) supports this view, as does the absence of alternations with a monophthongal vowel, characteristic of the native diphthongs.
} 
Nouns can take either one of the three plural markers in the language: $-C^{j}$ (palatalization of the final consonant of the stem), $-u r^{j}$, and $-e$. The palatalization of the first two markers (underlyingly a high vowel), triggers a classic case of metaphony, common in Romance languages. I illustrate it first for the a-ə alternation:

\begin{tabular}{|c|c|c|c|}
\hline \multicolumn{2}{|c|}{$\begin{array}{l}\text { Metaphony } \\
\text { Singular (á) }\end{array}$} & \multicolumn{2}{|c|}{ Plural (á -j) } \\
\hline karte & ‘book’ & $k{ }^{\prime} t s^{j}$ & 'books' \\
\hline tsara & 'country' & $t s \partial r^{j}$ & 'countries' \\
\hline barkə & 'boat' & bərt $\int^{j}$ & 'boats' \\
\hline vale & ‘valley' & & 'valleys' \\
\hline korare & 'path’' & $k \partial r \partial r^{j}$ & 'paths' \\
\hline
\end{tabular}

Similarly, the diphthongs do not surface before the high vowel of the plural marker, but mid [e] and [o] surface instead. This suggests that in Romanian /a/ and the diphthongs pattern together as low vowels with respect to metaphony, and $/ \partial /, / \mathrm{e} /, / \mathrm{o} /$ pattern together as mid vowels. This type of metaphony which causes a stressed low vowel to rise is identical to the one found for example in Italian (Maiden 1991) or Lena Bable (Hualde 1989). Romanian examples containing the diphthongs are given below:

\begin{tabular}{|c|c|c|}
\hline $\begin{array}{l}\text { Singular (éá) } \\
\text { searə }\end{array}$ & $\begin{array}{l}\text { Plural (é-j) } \\
\operatorname{ser}^{j}\end{array}$ & 'evening' \\
\hline kreangə & krend $^{j}$ & 'branch' \\
\hline viteaz & vite $^{j}$ & 'brave'm. \\
\hline mofneag & $\operatorname{mo\int ned} z^{j}$ & 'old man' \\
\hline streafinə & ${\text { stre } \int i n^{j}}^{j}$ & ‘eaves’ \\
\hline searbəd & serbez ${ }^{j}$ & 'bland' \\
\hline teafor & tefer $^{j}$ & ‘safe’' \\
\hline greatsə & grets-ur $^{j}$ & 'nausea' \\
\hline treabə & treb-ur ${ }^{j}$ & 'task’ \\
\hline
\end{tabular}

The diphthong /oa/ is also subject to height harmony, as shown by the oa-o alternations in the singular-plural pairs below:

$\begin{array}{lll}\text { Singular (oá) } & \text { Plural (ó-j) } & \\ \text { boalə } & \text { bol }^{j} & \text { 'illness' } \\ \text { poartə } & \text { ports }^{j} & \text { 'gate' } \\ \text { roatə } & \text { rots }^{j} & \text { 'wheel' } \\ \text { floare } & \text { flor }^{j} & \text { 'flower' }\end{array}$

It is important to note, however, that all of the forms in (24)-(26) are feminine. As I will discuss in more detail in Section 6, some occurrences of the diphthongs are morphologized. We will see that in masculine nouns metaphony 
does not affect /oa/. There is therefore a divergence in the behavior of the two diphthongs with respect to metaphony. The diphthong /oa/ still surfaces under stress in masculine plural forms (27a), while the other diphthong, /ea/, does not (27b). ${ }^{4}$
a. Singular (oá) Plural (oá-j

$\begin{array}{lll}\text { oaspete } & \text { oaspets }^{\hat{j}} & \text { 'guest' } \\ \text { joaretse } & \hat{\text { Joaretf }}^{j} & \text { 'mouse' }\end{array}$
b. Singular (éá) Plural (é-j)

$\begin{array}{lll}\text { streafinə } & \text { strefin }^{j} & \text { 'eaves' } \\ \text { mesteakon } & \text { mestetfen }^{j} & \text { 'birch' } \\ \text { teafor } & \text { tefer }^{j} & \text { 'safe' }\end{array}$

The second type of metaphony is triggered by the plural marker $-e$, and only affects the diphthong /ea/. The diphthong does not surface in the stressed syllable of the stem before the plural suffix, and /e/ surfaces instead.

$\begin{array}{lll}\text { Singular (ęá) } & \text { Plural (é-e) } & \\ \text { fereastrə } & \text { ferestre } & \text { 'window' } \\ \text { tręazə } & \text { treze } & \text { 'awake' f. } \\ \text { béatə } & \text { bete } & \text { 'drunk' f. } \\ \text { tseastə } & \text { tseste } & \text { 'skull' } \\ \text { têfərə } & \text { tefere } & \text { 'safe' f. } \\ \text { tseapənə } & \text { tsepene } & \text { 'stiff' f. }\end{array}$

The fact that /oa/ is unaffected is illustrated by the singular-plural pairs in (29a) below, and by the singular forms in (29b), where - $e$ is a desinence vowel (masculine or feminine).

$\begin{array}{lll}\text { a. Singular } & \text { Plural (-e) } & \\ \text { poamə } & \text { poame } & \text { 'fruit' } \\ \text { tóanə } & \text { toane } & \text { 'whim' } \\ \text { doamnə } & \text { doamne } & \text { 'lady' } \\ \text { koroanə } & \text { koroane } & \text { 'crowns' } \\ \text { proaspətə } & \text { proaspete } & \text { 'fresh'f. }\end{array}$

\footnotetext{
4. I found only one feminine form which preserves oa in the plural (foarfekə -foarfetf' 'scissors'), but for this noun the $-e$ plural is also attested (foarfet fe). Moreover, the dictionary lists this noun as belonging to any one of the three genders.
} 
b. Desinence (e)

$\begin{array}{ll}\text { floare } & \text { 'flower' } \\ \text { soare } & \text { 'sun' } \\ \text { boare } & \text { 'breeze' } \\ \text { ploaje } & \text { 'rain' } \\ \text { onoare } & \text { 'honor' }\end{array}$

Having established the phonological restrictions on the occurrence of the diphthongs, we now have to determine their phonemic status. I argue that some of the diphthongs are underlying, and evidence can be found in the existence of (near) minimal pairs in the language, such as those listed below.

\begin{tabular}{|c|c|c|c|}
\hline boalə & 'illness' & boltə & 'arch' \\
\hline kôapsə & 'hip' & kobzə & string instrument \\
\hline toarto & 'handle' & tortsə & 'torch' \\
\hline poarto & 'gate' & poftə & 'appetite' \\
\hline sêra & 'evening' & serə & 'greenhouse' \\
\hline têamə & 'fear' & temə & 'theme' \\
\hline$\hat{d z e}$ еапә & 'eyelash' & dzепә & 'gene' \\
\hline fleak & 'trifle' & flek & 'shoe heel' \\
\hline beat & 'drunk'm. & bek & 'light bulb' \\
\hline
\end{tabular}

Based on the fact that the occurrence of the diphthongs is not always predictable, I would like to suggest instead that at least some of them are phonemic at the current stage of the language. Recall the historical rules presented in Section 4, which diphthongize / $/ \mathrm{a}$ and / $/$ / in Common Romanian. All historical analyses agree that at that stage of the language the diphthongs are entirely phonologically conditioned. In Modern Romanian, however, there is evidence for a dual status of the diphthongs. Some are underlying, and some are phonologically and morphologically conditioned. Synchronic analyses, as I have shown, continue to assume that the diphthongs are derived, and no mention is made of morphologically-based generalizations. I would like to suggest that at some point the diphthongization rules stopped being active as purely phonological rules. It is quite plausible, in fact, that the particular triggering and blocking environments of the rules described so far resulted in a rather systematic distribution of the diphthongs with respect to the morphological categories of gender and person. This could gradually lead to their reinterpretation as fulfilling a morphological function. The presence of this new morphologization stage could in turn explain the phonemicization of some of the diphthongs. The diphthongs which remain unassociated with a particular morphological role become unpredictable, and are reinterpreted as phonemic. I postpone until the next section the formal analysis of morphologization. In the 
remainder of this section I will continue to focus on the phonological aspects of diphthongization.

I argue that the occurrence of the diphthongs is driven by a preference for low vowels to surface under stress. Low vowels have been shown to be the preferred stress-bearing nuclei in a number of languages, studied by Kenstowicz (1994). Kenstowicz shows that the location of stress is correlated with the relative sonority of vowels. In keeping with this evidence, I propose that Romanian stress is to some extent sensitive to vowel height, and I adopt Kenstowicz's proposed family of constraints *Peak, which form a Peak Prominence scale. For Romanian the Peak Prominence scale is defined over syllables:

$$
\text { *Peak/ə } \gg * \text { Peak/i,u } \gg * \text { Peak/e,o } \gg * \text { Peak/a }
$$

The scale captures the generalization that [ə] is the least preferred syllable nucleus under stress, followed by high vowels, mid vowels, and low vowels. The fixed constraint sub-hierarchy I am assuming can also be expressed in terms of number of aperture particles, following Schane's model:

$$
\begin{aligned}
* P e a k & \left|\mathrm{a}^{0}\right| \gg * \text { Peak } / \mathrm{a}^{1}\left|\gg * \mathrm{Peak} / \mathrm{a}^{2}\right| \text { where } \\
\left|\mathrm{a}^{0}\right| & =\text { zero aperture particles }\{\mathrm{i}, \mathrm{i}, \mathrm{u}\} \\
\left|\mathrm{a}^{1}\right| & =\text { one aperture particle }\{\mathrm{e}, \partial, \mathrm{o}\} \\
\left|\mathrm{a}^{2}\right| & =\text { two aperture particles }\{\underset{n}{\mathrm{a}}, \mathrm{a}, \mathrm{oa}\}
\end{aligned}
$$

Notice that for a vowel system like that of Romanian, with both a mid and a high central vowel, Schane's particle model predicts that /// patterns with the other mid vowels with respect to the *Peak constraint. In most languages that contain / $/$ /, this vowel is the least preferred prominence peak. This does not seem to be the case in Romanian, however. As shown earlier, in Romanian underlying /a/ does surface under stress. This fact suggests the ranking IDENT$\mathrm{IO}[ə] \gg *$ Peak/ə, but makes no prediction regarding the status of $/ \curvearrowright /$ relative to the other two mid vowels.

The interaction of *Peak constraints with Faithfulness constraints accounts for the phonological distribution of diphthongs in non-metaphony environments. Notice first of all that none of the examples given so far involve high vowels. These do not participate in the alternations (e.g., mík-mit $\int^{j}$ 'small' sg.pl.). I first illustrate the constraint interaction in the case of an underlying high vowel. The relevant constraints are ${ }^{*} \mathrm{Peak} / \mathrm{Ia}^{0} \mathrm{I}$ and IDENT-IOla ${ }^{0} \mathrm{I}$. ${ }^{*} \mathrm{Peak} / \mathrm{a}^{0} \mathrm{I}$ is basically the equivalent of $* \mathrm{Peak} / \mathrm{i}, \mathrm{u}$, and prohibits high vowels (with zero aperture particles) from surfacing under stress. IDENT-IOla ${ }^{0} \mid$ is the equivalent of IDENT-IO[+high]. It requires the output vowel to preserve the same number of aperture particles (in this case zero) as the correspondent input vowel. In a featural representation it would require the two correspondent vowels to have the same value for the feature [high]. 
The ranking IDENT-IOla ${ }^{0} I \gg * P e a k / / a^{0} I$ predicts a surface form containing a stressed high vowel.

IDENT-IOla ${ }^{0} \mid \gg *$ *Peak/la ${ }^{0} \mid$
mík 'small' (masc. sg.)
\begin{tabular}{|c|c|c|}
\hline$/$ mik/ & IDENT-IOla ${ }^{0} \mid$ & ${ }^{* P e a k} / \mathrm{a}^{0} \mid$ \\
\hline mík & & $*$ \\
\hline mék & $* !$ & \\
\hline méák & $* !$ & \\
\hline mák & $* !$ & \\
\hline
\end{tabular}

The first candidate is the only one which satisfies the higher ranking faithfulness constraint by maintaining zero aperture particles. It is therefore the selected output, although it violates *Peak by allowing a high vowel to surface under stress.

The *Peak constraints interact with one other constraint, resulting in the metaphony which occurs in the presence of the inflectional markers ${ }^{j}$ and $-e$, respectively. I propose that this constraint which conflicts with *Peak is an IDENTITY constraint between an element of the stem and an element of the suffix. If we unpack the generalization behind metaphony, we see that it refers to identity in vowel height between the stressed vowel of the stem and the vowel of the suffix. The relevant constraint can therefore be conceived of as one evaluating the correspondence between two elements of the same output representation: the stressed vowel of the stem and the vowel of the suffix. The output is evaluated by comparing the two elements, and assessing how closely they match in terms of height. Based on these considerations I propose the constraint below as one which best captures metaphony.

\section{IDENT-StSflal}

(where $\mathrm{St}=$ stem, $\mathrm{Sf}=$ suffix)

The stressed vowel of the stem must match the aperture of the inflectional suffix vowel.

This identity is required only before inflectional suffixes containing front vowels ([i] and [e]). We will also see evidence for two instantiations of the constraint, relatively ranked, one in the presence of a high vowel (IDENT-StSfla ${ }^{0} \mid$ ), and one in the presence of a mid vowel (IDENT-StSfla ${ }^{1} \mid$ ). I illustrate below a simple constraint interaction featuring IDENT-StSflal ${ }^{5}$. IDENT-StSflal presupposes that the stem and the suffix are related by correspondence. Exactly how

5. See Baković (2000) for a similar approach to vowel harmony. He proposes the AgREE[F] family of constraints, but considers them to be part of Faithfulness. 
correspondence should be defined between these two elements remains a matter for further study. What is important for now is to see the parallel between metaphony and identity.

IDENT-StSflal is gradiently violated, depending on the number of aperture particles separating the stressed vowel of the candidate form from the vowel of the suffix. The case below involves the nominal plural suffix ${ }^{j}$ in the alternation sear $-\operatorname{ser}^{j}$ 'evening'. The ranking of IDENT-StSflal above *Peak/la ${ }^{1}$ ' predicts /e/ in the presence of the plural suffix $-u r^{j}$, as in treabə-trebur ' 'task'. For simplicity, I will assume that stress is underlyingly marked in Romanian, therefore no stress-related constraints will be included in the tableaux.

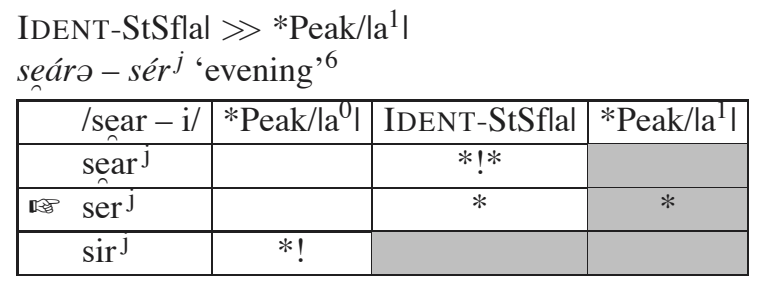

The tableau above shows first of all why the diphthong cannot surface in plural forms. Although, as a low vowel, it best satisfies the sonority requirement for a stressed vowel, it incurs two violations of IDENT-StSf, due to its two aperture particles that separate it from the suffix vowel. IDENT-StSf is best satisfied by the third candidate containing the high vowel /i/, which best matches the /i/ of the suffix. But this same candidate violates $* P e a k / a^{0} I$, higher in the Prominence Scale, by allowing the same high vowel under stress. The second candidate, containing /e/, is the optimal one. The stressed mid vowel is only one aperture particle away from the suffix vowel, and is better tolerated under stress than a high vowel.

The same constraint interaction predicts the effect of IDENT-StSflal in the presence of the plural suffix $-e$, in the alternation $d_{3}$ ean $-d_{3}$ ene 'eyelash'.

\begin{tabular}{|c|c|c|c|c|c|}
\hline & $/ \mathrm{d}$ zean $-\mathrm{e} /$ & ${ }^{*}$ Peak $/ \mathrm{a}^{0} \mid$ & IDENT-IOlil & IDENT-StSflal & *Peak/la ${ }^{1} \mid$ \\
\hline & dzeane & & & $* !$ & \\
\hline 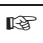 & dzene & & & & * \\
\hline & dzəne & & $* !$ & & * \\
\hline & dzine & $* !$ & & * & \\
\hline
\end{tabular}

6. I will not discuss here the constraint interaction responsible for the surface realization of the plural suffix /-i/ as palatalization. 
An additional constraint is relevant here: IDENT-IOlil. In a featural representation this constraint would be the equivalent of IDENT-IO[-back], requiring correspondent segments to be identical in the type of particle (lil) or value for the feature [back]. IDENT-IOlil is the constraint which selects the output dzene over the candidate with [ə]. Both candidates contain a mid vowel that matches the vowel of the suffix. The same mid vowel also violates low ranking *Peak/la ${ }^{1}$. In addition, [ə] is missing a palatality particle, which eliminates the candidate.

The diphthong in the first candidate cannot surface in the plural form because it contains one lal particle too many, failing to match the suffix vowel. The last candidate containing [i] is eliminated because it contains a high vowel under stress, and furthermore lacks an lal particle to match the suffix vowel.

One more fact left to account for is the absence of a metaphony effect on underlying forms containing the diphthong /oa/. The absence of metaphony can be observed in masculine nouns (e.g., the singular-plural alternation oaspete oaspets $^{j}$ 'guest') and in feminine nouns only before the plural marker $-e$ (e.g., poam -poame 'fruit'). These facts can be accounted for by assuming high ranking faithfulness to the diphthong /oa/. Thus, by outranking IDENT-StSf, IDENT-IO[oa] predicts that the diphthong /oa/ occurs in the plural forms. A simple tableau illustrates this ranking below.

poámə - poáme 'fruit'
\begin{tabular}{|l|c|c|}
\hline /poam - e/ & IDENT-IO[oa] & IDENT-StSflal \\
\hline poame & & $*$ \\
\hline pome & $* !$ & \\
\hline peme & $* !$ & \\
\hline
\end{tabular}

High ranking IDENT-IO[oa] thus eliminates the last two candidates, although they both contain mid vowels, matching the suffix vowel.

Before moving on to the discussion of the á-á alternations in the next section, I summarize below the constraints proposed so far.

$$
\begin{aligned}
& \text { IDENT-IOla }{ }^{0} \mid \gg * *^{*} \text { Peak } / \mathrm{la}^{0} \mid \gg \text { IDENT-StSflal } \gg * \text { Peak } / \mathrm{a}^{1} \mid \\
& \text { IDENT-IO[oa] } \\
& \text { IDENT-IOlil }
\end{aligned}
$$

The subhierarchy IDENT-IOla ${ }^{0} \mid \gg *$ Peak/la ${ }^{0} \mid$ predicts that high vowels are unaffected by stress. The ranking IDENT-StSflal $\gg *$ Peak $/ \mathrm{a}^{1} \mid$ accounts for the fact that underlying /ea/ surfaces as mid [e] under stress in a metaphony environment (e.g., seár - sér ${ }^{j}$ 'evening'). IDENT-IO[oa] 》 IDENT-StSflal explains why the back diphthong is not affected by metaphony, at least not before -e (e.g., poámə -poáme 'fruit'). The /oa/ diphthong shows an asymmetric behavior to which I will return in Section 6. Finally, IDENT-IOlil $\gg$ 
IDENT-StSflal predicts that only height (aperture) is affected in metaphony, but other particles, such as palatality, are preserved. The ranking selects $d_{3}$ ene over *dzəne, both containing stressed mid vowels.

It should be noted that the lower ranking constraint, $*$ Peak/la ${ }^{1}$ I has not played a crucial role so far. In fact, in the previous tableaux, it could have been replaced by faithfulness to the /ea/ diphthong of the input, without affecting the winning output form. Evidence for ${ }^{*} \mathrm{Peak} / \mathrm{a}^{1} \mathrm{l}$, rather than IDENT-IO[ea] will be seen, however, in the next sections, in the case of underlying forms containing mid vowels.

\subsection{The phonological behavior of the low vowel a}

My claim that the diphthongs pattern as low vowels is based on the existence of similar alternations between [a] and [ə] under stress. It is true that á-ó alternations occur less often than mid vowel-diphthong alternations. This difference can be explained by the high ranking of both IDENT-IO[a] and IDENT-IO[ə]. High ranking IDENT-IO[a] explains the fact that stressed [a] is not affected by IDENT-StSf, with the very specific exception of feminine nouns which take the plural marker $-{ }^{j}$ and $-u r^{j}$. This suggests that the effect of metaphony on [a], unlike its effect on the diphthongs, is both morphologically and phonologically conditioned. The same two plural markers in masculine and neuter nouns do not trigger metaphony. Moreover, metaphony of [a] is also not triggered by the ${ }_{j} j$ plural marker in adjectives, nor by the ${ }_{-}^{j}$ second person marker in verbs. Examples of [a] metaphony are given below for feminine nouns (39a), compared with the absence of metaphony for masculine and neuter nouns (39b, c).

\begin{tabular}{|c|c|c|}
\hline \multicolumn{3}{|c|}{$\begin{array}{l}\text { Feminine nouns (á-á) } \\
j j \text { plural }\end{array}$} \\
\hline baltə & bəlts $^{j}$ & 'puddle' \\
\hline vale & $v ə j$ & ‘valley’ \\
\hline kale & $k ə j$ & ‘road’' \\
\hline karte & $k{ }^{\prime} t s^{j}$ & ‘book’ \\
\hline mare & $m r^{j}$ & 'sea' \\
\hline stradə & stroz ${ }^{j}$ & 'street' \\
\hline ranə & $r \partial n^{j}$ & 'wound' \\
\hline barkə & bərt $\int^{j}$ & 'boat' \\
\hline maskə & $m \partial \int t^{j}$ & 'mask' \\
\hline baykə & bənt $\int^{j}$ & 'bench' \\
\hline ogradə & $\operatorname{ograz}^{j}$ & 'courtyard' \\
\hline odaje & $o d ə j$ & 'room’' \\
\hline vәраje & vәрәј & 'flame' \\
\hline bətaje & bətəj & 'fight' \\
\hline
\end{tabular}


j plural

bukatə

kəmarə

kərare

sabije

salt ije

propastije

flakərə

tsandərə

strakinə

plapumə

pasəre

$-u r^{j}$ plural

blanə

marfo

otravo

karne

motase

minkare

sare

bukəts

'piece'

'pantry'

$k \partial m r^{j}$

$k_{\partial r \partial r^{j}}$

'path'

'sword'

'willow tree'

səlt $\int i j$

prəpəstij

'chasm'

fləkər ${ }^{j}$

'flame'

tsəndər $^{j}$

'shred'

strakin ${ }^{j}$ 'bowl'

pləpum $^{j} \quad$ 'cover'

pəsər $^{j}$

'bird'

blənur $^{j} \quad$ 'fur'

morfur $^{j}$

otrəvur $^{j}$

'merchandise'

'poison'

kərnur $^{j} \quad$ 'meat'

mətəsur $^{j} \quad$ 'silk'

minkərur ${ }^{j}$ 'food'

sərur ${ }^{j} \quad$ 'salt'

b. Masculine nouns (á)

( ${ }^{j}$ plural)

$\begin{array}{lll}\text { kal } & \text { kaj } & \text { 'horse' } \\ \text { brad } & \text { braz }^{j} & \text { 'fir tree' } \\ \text { sak } & \text { satf }^{j} & \text { 'sack' } \\ \text { pas } & \text { paf }^{j} & \text { 'footstep' } \\ \text { stezar } & \text { stezar }^{j} & \text { 'oak tree' } \\ \text { fazan } & \text { fazan }^{j} & \text { 'pheasant' } \\ \text { frate } & \text { frats }^{j} & \text { 'brother' }\end{array}$

c. Neuter nouns (á)

(-ur ${ }^{j}$ plural)

$\begin{array}{lll}\text { val } & \text { valur }^{j} & \text { 'wave' } \\ \text { salt } & \text { saltur }^{j} & \text { 'leap' } \\ \text { pat } & \text { patur }^{j} & \text { 'bed' } \\ \text { park } & \text { parkur }^{j} & \text { 'park' } \\ \text { lak } & \text { lakur }^{j} & \text { 'lake' } \\ \text { gard } & \text { gardur }^{j} & \text { 'fence' } \\ \text { dar } & \text { darur } & \text { 'gift' }\end{array}$

The [a] metaphony restricted to feminine nouns is not without exception. Most of the exceptions are loanwords or recent formations. For example, feminine nouns ending in -tsie do not undergo metaphony in the plural, although they 
take the ${ }^{j}$ plural marker, realized as a full glide after a vowel (e.g., reáktsie - reáktsij 'reaction'; okupátsie - okupátsij 'occupation'). A few of the nouns, such as those in (40) are, however, native, and must be considered lexical exceptions:

$\begin{array}{lll}\begin{array}{l}\text { Exceptions } \\ \text { vakə }\end{array} & \\ \text { pazifte } & \text { vat }^{j} & \text { 'cow' } \\ \text { lakrimə } & \text { lakrim }^{j} & \text { 'lawn' } \\ \text { patimə } & \text { patim }^{j} & \text { 'tear' } \\ \text { payglikə } & \text { payglitf } & \text { 'passion' } \\ \text { ramurə } & \text { ramur } & \text { 'ribbon' } \\ \text { afkie } & \text { afkij } & \text { 'branch' } \\ \text { sartfinə } & \text { sartfin } & \text { 'splinter' } \\ \text { mardzine } & \text { mardzin } & \text { 'task' } \\ \text { mard } & \text { 'edge' }\end{array}$

Stressed [a] is not affected by IDENT-StSf. It surfaces for example before the desinence $-e$, and before the plural marker $-e$ in both feminine and neuter nouns.

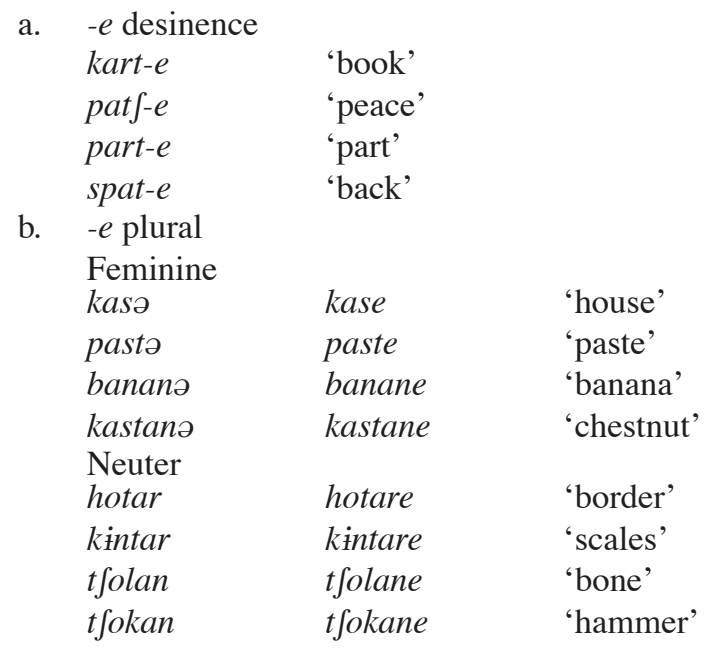

The observed resistance to metaphony suggests that IDENT-IO[a] outranks IDENT-StSf. This ranking will not account for the feminine nouns, which will be analyzed in the next section.

High ranking IDENT-IO[ə] explains why [ə] always surfaces under stress, without being affected by *Peak/ə. The ranking IDENT-IO[ə] $\gg$ Peak/ə accounts for the fact that [ə] does not lower to [a] in forms such as məturə 'broom', páturə 'blanket', ásta 'this one'(colloquial form). 
I have shown so far how the phonological constraints of the Peak Prominence scale can account for diphthongization and for the phonological conditioning of the mid-low vowel alternations. It is quite clear, though, that these alternations are not driven exclusively by the phonology, and in Section 6 I discuss their morphological behavior.

Before moving on to the morphology, however, I will show how the analysis proposed so far allows us to integrate Romanian typologically with other languages that show a relation between vowel height and stress.

\subsection{Vowel height and stress}

I repeat below some of the examples which illustrate the distribution of vowels with respect to stress.

$\begin{array}{llll} & \text { Singular } & \text { Plural } & \\ \text { ə-á } & \text { kárte } & \text { kárts }^{j} & \text { 'book' } \\ e-\text { eá } & \text { beát } & \text { béts }^{j} & \text { 'drunk' } \\ o-\text { óa } & \text { poártə } & \text { pórts } & \text { 'gate' }\end{array}$

High vowels do not participate in this alternation.

$$
\begin{array}{lll}
\text { mík } & \text { mit }^{j} & \text { 'small' } \\
\text { bún } & \text { bún }^{j} & \text { 'kind' } \\
\text { gínd } & \text { gínd-ur } & \text { 'thoughts' }
\end{array}
$$

The examples in (42) show that the low vowel [a] and the diphthongs [ea] and [oa] pattern together. All three surface under stress in the left column. In the right column the mid vowels surface, although they are still stressed, as a result of a conflicting metaphony factor. Given their identical distribution, I have proposed that the two diphthongs [ea] and [oa] are actually low vowels in the system, front and back, respectively.

When a derivational suffix is added to a stem, the suffix is stressed. In that case the underlying low vowels of the unstressed stem surface as mid. We find the following alternations:

$\begin{array}{lllll} & \text { Stressed } & & \text { Unstressed } \\ \text { á-ə } & \text { kárte } & \text { 'book' } & \text { kərt-itfíkə } & \text { (diminutive) } \\ \text { eá-e } & \text { beát } & \text { 'drunk' } & \text { bets-ív } & \text { 'who drinks a lot' } \\ \text { oá-o } & \text { poártə } & \text { 'gate' } & \text { port-ítsə } & \text { (diminutive) }\end{array}$

The alternation of stressed [a] with unstressed [ə] may appear to be an instance of vowel reduction, similar to that found in English, for example. However, schwa is not a phonologically reduced vowel in Romanian, and it has 
phonemic status. It may itself surface under stress, and there is evidence for underlying /a/ in a number of forms. The roots in (45a), for example, all contain underlying / $/$ /, which surfaces in both stressed and unstressed positions. The schwas in (45b) do not alternate with any other vowels, and their occurrence is unpredictable, thus supporting the view that they are part of the underlying representation of these forms. Finally, (45c) contains some minimal pairs.
a. mátura
'broom'
páturə
b. pəmint 'earth'
pərinte 'parent'
grotár 'grill'
mətur-íkə
(diminutive)
'blanket'
pətur-íkə
(diminutive)
c. pár
'hair'
'stick'
pár
'pole'
báts
bóts
'a small amount'

Cross-linguistically, the most common instantiation of prominence is weight, and in many languages vowels diphthongize under stress. There is evidence, however, that the stress system of Romanian is not weight sensitive (Chitoran 1996, 1997, 2001). The Romanian diphthongs thus satisfy a qualitative, rather than a quantitative requirement on stress, and are best treated as low vowels.

The preference for low vowels in positions of prominence manifests itself differently in Romanian than in the languages studied by Kenstowicz (1994), namely Chukchee, Kobon, Aljutor, Mordwin and Mari. In these languages the syllable containing the most sonorous vowel surfaces as the head of a foot regardless of its position in the prosodic word. Other requirements, such as relative distance from the edge, the moraic or syllabic binarity of feet, and the exhaustive parsing of syllables into feet, are neglected in favor of ensuring that the stressed vowel be low. In Romanian, on the other hand, instead of seeking out the lowest vowel in the prosodic word, stress is systematically assigned to the rightmost syllable, but changes the quality of the vowel in some cases, namely when that vowel is not sufficiently sonorous. Kenstowicz's observation, then, opens the way to four possible interactions of stress and sonority:

(46) (i) No interaction - stress is not sensitive to vowel quality (most languages).

(ii) Stress looks for the most sonorous peak in the prosodic word (languages discussed by Kenstowicz).

(iii) Stress is fixed, but the quality of the stressed vowel changes to form the most sonorous peak (Romanian, Squamish).

(iv) Stress is fixed, but the quality of the unstressed vowel(s) changes to become less sonorous than the stressed vowel (Romanian, Catalan, Brazilian Portuguese). 
Types (ii-iv) can be grouped together as languages with sonority-driven stress. This generalization can be best captured in an OT framework, by the different rankings of three types of constraints: (a) IDENT-IO(F) (faithfulness to the height feature of the input vowel); (b) markedness constraints on foot type or on the location of stress (e.g., FOOT-Form, Rightmost, or NoNFINALITY), and (c) the constraint which requires the stressed vowel to be sonorous (e.g., ${ }^{*}$ Peak/V). The intuitive relationship between the three language types falls out easily from this formalism, something harder to achieve in procedural terms. I sketch out below the three possible constraint rankings predicting (i-iii). Type (iv) is predicted by the same ranking as type (iii), with an additional markedness constraint $\mathrm{C}$, whose ranking in the grammar predicts the height of the unstressed vowel in the stem.

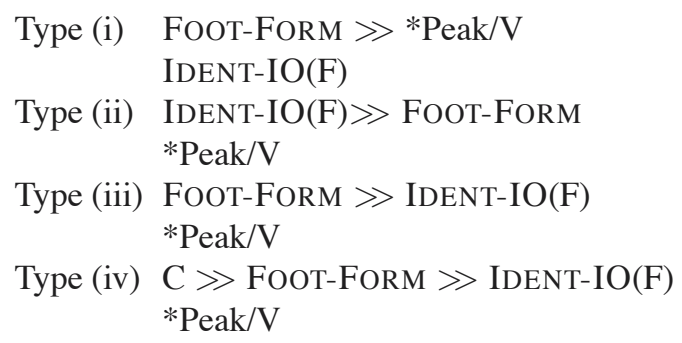

In Romanian, essentially a type (iii) language, in order to fulfill the sonority requirement, faithfulness to the input is violated, allowing the stressed vowel to surface as low.

\section{The morphological conditioning of mid-low vowel alternations}

\subsection{Generalizations}

This section discusses the distribution of diphthongs and low vowels in morphological alternations. The major generalizations that can be made involve the category of gender in nouns and adjectives, and the category of person in verbs. My analysis will focus on gender, and I will therefore begin by explaining how gender is marked in Romanian.

Romanian has a three-gender system, masculine, feminine, and neuter. Neuter nouns are actually ambigenous, masculine in the singular and feminine in the plural. These nouns therefore have no markers of their own. In the singular, they share with masculine nouns their desinence vowels or absence thereof. This is best seen by looking at the distribution of desinence vowels by gender, as schematized below. The chart also indicates in the cells which vowels can 
surface under stress for each gender-desinence vowel combination. The shaded cells indicate desinences shared by two genders.

(48) Distribution of desinence vowels and stressed stem vowels by gender (singular nouns)

\begin{tabular}{|c|c|c|c|c|}
\hline Singular & $\varnothing$ & {$[-\mathrm{u}]$} & [-e] & [-ə] \\
\hline M & $\begin{array}{l}\text { é, ó, á } \\
\text { eá, oá, á }\end{array}$ & $\begin{array}{c}\text { é, ó, á } \\
\text { á }\end{array}$ & $\begin{array}{l}\text { é, ó } \\
\text { oá, á }\end{array}$ & \\
\hline F & & & $\begin{array}{l}\text { é, ó } \\
\text { oá, á }\end{array}$ & $\begin{array}{l}\text { é, ó, á } \\
\text { eá, oá, á }\end{array}$ \\
\hline $\mathrm{N}$ & $\begin{array}{l}\text { é, ó, á } \\
\text { eá, oá, á }\end{array}$ & & & \\
\hline
\end{tabular}

We can see that masculine and neuter nouns share the $\emptyset$-desinence, while masculine and feminine nouns share the $-e$ desinence. The overlap between masculine and neuter forms with $\emptyset$-desinence results in a neutralization of the masculine-neuter distinction in the singular. The overlap between masculine and feminine forms in nouns with the - $e$ desinence does not result in neutralization, because the agreement patterns still differ (masculine vs. feminine). It is interesting to compare the situation in the singular to the one in the plural. I schematize below the distribution of plural noun markers by gender, again indicating in the cells the nature of the stressed vowel of the stem.

Distribution of plural noun markers and stressed stem vowels by gender

\begin{tabular}{|c|c|c|c|}
\hline Plural & {$\left[{ }^{-j}\right]$} & {$\left[-\mathrm{ur}^{\mathrm{j}}\right]$} & {$[-\mathrm{e}]$} \\
\hline M & $\begin{array}{l}\text { é, ó } \\
\text { oá, á }\end{array}$ & & \\
\hline $\mathrm{F}$ & $\begin{array}{l}\text { é, ó, á } \\
\text { á }\end{array}$ & é, á & $\begin{array}{l}\text { é, ó } \\
\text { oá, á }\end{array}$ \\
\hline $\mathrm{N}$ & & $\begin{array}{l}\text { é, ó } \\
\text { eá, á }\end{array}$ & $\begin{array}{c}\text { é } \\
\text { eá, oá, á }\end{array}$ \\
\hline
\end{tabular}

The table shows that all three plural markers are shared by two genders. The feminine, in particular, can take any one of the three markers. Two of these, $-u r^{j}$ and $-e$, are shared with the neuter, which, moreover, has feminine agreement patterns in the plural. The distinction between feminine and neuter is thus considerably minimized in the plural. Given its ambigenous nature, the neuter inevitably overlaps with the other two genders. It is possible that within such a system with a lot of overlap, the quality of the stressed vowel of the stem is prone to reinterpretation as an auxiliary morphological marker which helps distinguish the three gender categories. 
This is in fact the only possible explanation for the data discussed in the previous section, involving the a-r alternation. I showed that the effect of metaphony is found exclusively in feminine nouns, before the plural markers ${ }^{j}$ and $-u r^{j}$. The same plural markers in masculine or neuter nouns do not trigger metaphony. Similarly, metaphony does not affect the stressed vowels of adjectives or verbs. This is the only instance of a morphological á-ź alternation. The more numerous morphologized alternations involve the diphthongs. I present below the relevant data to be analyzed, organized by morphological category: adjectives, verbs, nouns.

Instances of derived diphthongs in the following examples are written in boldface. Within the class of adjectives (as well as animate nouns), for example, $o-O a$ and $e-e a$ alternations are found between masculine and feminine forms. When the diphthong is underlying, it will surface in all environments where it is not blocked by the restrictions discussed in the preceding section. This is, for example, the case of adjectives such as proaspot 'fresh', where the diphthong always surfaces, as well as teafor 'safe' and beat 'drunk', where IDENT-StSf intervenes to prevent the diphthong from surfacing in the plural forms of both genders. In forms containing an underlying mid vowel, the mid vowel surfaces in the masculine forms, and the diphthong surfaces in the feminine.

\begin{tabular}{|c|c|c|c|c|c|c|}
\hline & \multicolumn{3}{|c|}{ loá/ } & \multicolumn{3}{|c|}{ /ó/ } \\
\hline & Singular & Plural & & Singular & Plural & \\
\hline \multirow[t]{4}{*}{ M } & proaspot & proaspets $^{j}$ & & frumos & frumo $^{j}$ & ‘beautiful’ \\
\hline & & & & domn & domn $^{j}$ & 'gentleman' \\
\hline & & & & hots & hots $^{j}$ & 'thief' \\
\hline & & & & baron & baron $^{j}$ & 'baron’' \\
\hline \multirow[t]{5}{*}{$\mathrm{F}$} & proaspətə & proaspete & 'fresh' & frumoasa & frumoase & 'beautiful' \\
\hline & & & & doamnə & doamne & 'lady' \\
\hline & & & & hoatsə & hoatse & 'thief' \\
\hline & & & & baroano & baroane & 'baroness' \\
\hline & \multicolumn{3}{|c|}{ /ená/ } & \multicolumn{3}{|c|}{ lé/ } \\
\hline M & teafor & tefer ${ }^{j}$ & 'safe' & sek & $\operatorname{set}^{j}$ & 'dry’' \\
\hline & beat & bets $^{j}$ & 'drunk' & intreg & intred $3^{j}$ & 'whole' \\
\hline \multirow[t]{2}{*}{$\mathrm{F}$} & teafərə & tefere & & seakə & $\operatorname{set}^{j}$ & \\
\hline & beato & bete & & intreago & intred $z^{j}$ & \\
\hline
\end{tabular}

The same alternation is found in the vowel of the adjectival suffixes -os, -or, and -esk: 


\begin{tabular}{|c|c|c|}
\hline \multicolumn{3}{|c|}{ Adjectival suffixes (M/F) } \\
\hline -os / -oas-ə & fúrije & ‘fury’ \\
\hline & furj-ós, furj-oás-ə & ‘furious’ \\
\hline -or / -oar-e & $\begin{array}{l}\text { obosít } \\
\text { obosit-ór, obosit-oár-e }\end{array}$ & $\begin{array}{l}\text { 'tired' } \\
\text { 'tiresome' }\end{array}$ \\
\hline -esk / -ęask-ə & $\begin{array}{l}\text { tínər } \\
\text { tiner-ésk, tiner-eask-ə }\end{array}$ & $\begin{array}{l}\text { 'young', } \\
\text { 'youthful' }\end{array}$ \\
\hline
\end{tabular}

The distribution of /oa/ and /eea/ suggests that, along with the desinence vowels, the diphthongs mark the feminine gender in the category of adjectives. Thus, in addition to the phonological restrictions already discussed, the diphthongs are further restricted to surface only in the feminine forms of adjectives. Furthermore, this generalization is restricted to native or core lexical items. Thus, loanwords or more recent formations do not show the alternation between the mid vowels and the diphthongs (this was previously noticed by Lombard 1974). Only the mid vowels surface, as shown below.

(52) No diphthongs in more recent forms

$\begin{array}{ll}\text { komód - komódə } & \text { 'comfortable' } \\ \text { blónd - blóndə } & \text { 'blond' } \\ \text { sóbru }- \text { sóbrə } & \text { 'serious' } \\ \text { korékt }- \text { koréktə } & \text { 'correct' } \\ \text { absént - abséntə } & \text { 'absent' } \\ \text { supérb - supérbə } & \text { 'superb' } \\ \text { inténs - inténsə } & \text { 'intense' } \\ \text { modérn-modérnə } & \text { 'modern' }\end{array}$

A similar argument can be made about the morphologization of diphthongs in the category of verbs. The two tenses where stress falls on the stem are the present indicative and subjunctive. In these tenses the diphthongs surface in the third person forms. The other forms in the paradigm contain the mid vowel.

(53) Verbs

Present indicative and subjunctive

\begin{tabular}{|c|c|c|c|c|}
\hline \multirow{4}{*}{$\begin{array}{l}1 \text { conj. } \\
2 \text { conj. } \\
4 \text { conj. }\end{array}$} & \multirow{4}{*}{$\begin{array}{l}1 \text { sing } \\
\text { skól } \\
\text { pót } \\
\text { dórm }\end{array}$} & \multirow{4}{*}{$\begin{array}{l}3 \text { indicative } \\
\text { skoálo }(\mathrm{sg} \text { and } \mathrm{pl}) \\
\text { poáte }(\mathrm{sg}) \\
\text { doárme }(\mathrm{sg})\end{array}$} & \multicolumn{2}{|c|}{3 subjunctive ( $\mathrm{sg}$ and $\mathrm{pl}$ ) } \\
\hline & & & skoále & 'get up' \\
\hline & & & poáto & 'be able to' \\
\hline & & & doármo & 'sleep' \\
\hline & plék & pleákə (sg and pl) & plét fe & \\
\hline & lukr-éz & lukr-eáz-ə & lukr-éze & 'work' \\
\hline & mérg & mérdze (sg) & meárgə & 'walk' \\
\hline & opr-ésk & opr-éft-e (sg) & opr-eásk-əə & ‘stop’ \\
\hline
\end{tabular}


Based on the distribution of the diphthongs, the generalization that can be made here is that the diphthongs, along with the person-marking inflections, mark the 3rd person in present tense verb forms. As in the case of adjectives, loanwords and more recent verbs do not show this alternation, and the mid vowels surface in all the forms of the paradigm.

(54) No diphthongs in more recent verbs (3rd person present indicative)

$\begin{array}{ll}\text { implórə } & \text { 'implores' } \\ \text { apróbə } & \text { 'approves' } \\ \text { dezvóltə } & \text { 'develops' } \\ \text { akórdə } & \text { 'grants' } \\ \text { rezólvə } & \text { 'solves' } \\ \text { adóptə } & \text { 'adopts' } \\ \text { spérə } & \text { 'hopes' } \\ \text { rezérvə } & \text { 'reserves' } \\ \text { akt féptə } & \text { 'accepts' } \\ \text { kontéstə } & \text { 'contests' }\end{array}$

So far we have seen that the distribution of both diphthongs correlates with gender in nouns and with person in verbs. Both diphthongs can be seen as marking the feminine gender in nouns and the 3rd person in verbs. In addition to these two morphological environments, the diphthongs have one other systematic but not completely parallel distribution in the plural form of neuter nouns. First, the diphthong [oa] always surfaces in neuter plural forms which take the $-e$ plural marker. The alternation is exceptionless, and is present even in loanwords and other recent forms.

$$
\begin{array}{ll}
\begin{array}{l}
\text { Neuter nouns (oá) } \\
\text { avjon-avjoane }
\end{array} & \text { 'airplane' } \\
\text { butoj-butoaje } & \text { 'barrel' } \\
\text { balon-bấloane } & \text { 'balloon' } \\
\text { baston-bâstoane } & \text { 'cane' } \\
\text { kuptor-kuptoare } & \text { 'oven' } \\
\text { kovor-kovoare } & \text { 'carpet' } \\
\text { ultfor-ult fôare } & \text { 'pitcher' }
\end{array}
$$

Just like [oa], the diphthong [e्a] also marks the neuter gender in nouns, but in a different way. The latter diphthong surfaces in neuter plural forms in environments where it would not be predicted, given the phonological restrictions on it. More specifically, [ea] surfaces in the plural forms of neuter nouns which take both plural markers, $-u r^{j}$ as well as $-e$, and where normally the stressed vowel of the stem is subject to IDENT-StSf. Both plural markers are shared by the feminine and the neuter. The surface generalization that emerges is that, everything else being equal, IDENT-StSf is obeyed by feminine nouns, where the 
mid vowels surface, but disregarded by the neuter nouns, where [ena] surfaces. The relevant examples are given below.

\begin{tabular}{|c|c|c|c|c|}
\hline \multicolumn{5}{|c|}{ Neuter nouns (ea) } \\
\hline \multirow{4}{*}{$\begin{array}{l}\text { Singular } \\
\text { leágon } \\
\text { téárkən } \\
\text { freámət }\end{array}$} & Plural $e$ & \multicolumn{3}{|c|}{ vs. Feminine (sing-plural) } \\
\hline & leágəne & ‘swing’ & tseápənə-tsépene & 'stiff'" \\
\hline & tfeárkəne & 'rings (eyes)' & seárbədə-sérbede & 'bland' \\
\hline & frénáməte & 'shiver' & & \\
\hline Singular & Plural $u r^{j}$ & & Feminine (sing-ple & \\
\hline fleák & fleákur j & 'trifle' & treábə-trébur ${ }^{j}$ & 'task' \\
\hline steág & steágur $^{j}$ & 'flag' & 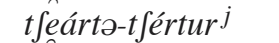 & 'quarrel \\
\hline leák & leákur ${ }^{j}$ & 'medicine' & 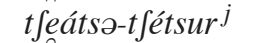 & 'fog' \\
\hline déál & deálur ${ }^{j}$ & ‘hill’ & greátsə-grétsur $^{j}$ & 'nausea' \\
\hline
\end{tabular}

The absence of alternation in the neuter nouns, and particularly the presence of the diphthong in the plural forms is in fact the only marker that distinguishes them from feminine nouns. Otherwise, neuter and feminine nouns share both plural marking suffixes and agreement patterns. Thus, at least for lexical items containing the diphthong /ea/, the neuter has its own marker, in addition to its ambigeneric properties.

To summarize, I identified four instances in which the distribution of the diphthongs is morphologically, as well as phonologically conditioned, and one instance in which the distribution of [ə] can be explained in the same way. In adjectives and animate nouns whose underlying representations contain mid vowels, the diphthongs predictably surface in the feminine forms, as long as they do not violate the phonological restrictions on their occurrence. The same is true of verbs, where the diphthongs predictably occur in the third person forms of the present indicative and subjunctive. A third, similar case is that of neuter nouns which contain the vowel /o/ underlyingly. The diphthong [oa] predictably surfaces in the plural forms of these nouns. The fourth case concerns neuter nouns which contain the diphthong /ea/ underlyingly. The diphthong systematically surfaces in the plural forms of these nouns, in violation of IDENT-StSf. Finally, in feminine nouns [ə] surfaces in plural forms as the expected result of metaphony. It does not surface, however, in other morphological categories where it would also be phonologically predicted.

In terms of the analysis, these generalizations suggest that phonological and morphological constraints can freely interact in the grammar. In the next section I propose an analysis of these facts relying crucially on morphologically specific constraints. 


\subsection{Analysis: Morphologization and morphologically-specific constraints}

The analysis I propose in this section is meant to capture the synchronic facts as presented in the two preceding sections. I first present an analysis of the phonological behavior of diphthongs without the morphological facts. I will then show how the constraints related to their morphological behavior interact with the other constraints in the hierarchy.

In the preceding section I proposed an account for the phonologically conditioned diphthongs based on the interaction of the *Peak constraints introduced in Section 5, with faithfulness constraints, including IDENT-StSf, which accounts for metaphony. The full constraint ranking is summarized below.

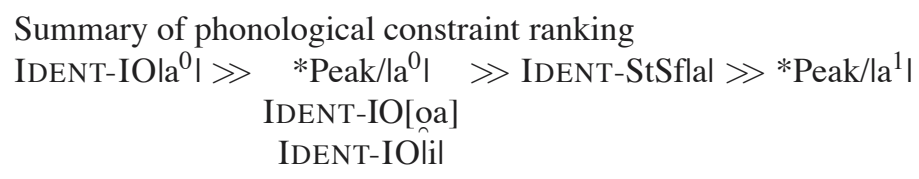

I propose that the morphologized alternations can be captured by the expansion of the *Peak constraints into a sub-hierarchy of morphologically specific constraints outranking the general, phonological ones. This proposal is inspired by lexically specific constraints proposed by several researchers to deal with exceptions (Itô and Mester 1999; Pater 2000, among others). I list below the morphologically specific *Peak constraints needed for the data discussed here.

$$
\begin{array}{ll}
\begin{array}{l}
\text { Morphologically specific wellformedness constraints } \\
\text { mid vowels are banned under stress in feminine }
\end{array} & \begin{array}{l}
\left.\mathrm{o}_{[\mathrm{adjF}]}\right] \\
\text { forms of adjectives (and animate nouns) }
\end{array} \\
{\left[* \text { Peak } / \mathrm{e}, \mathrm{O}_{[\mathrm{Verb} 3]}\right]} & \begin{array}{l}
\text { mid vowels are banned under stress in } 3^{\text {rd }} \text { person } \\
\text { forms of the present indicative and subjunctive }
\end{array} \\
{\left[* \text { Peak } / \mathrm{o}_{[\text {neuter }]}\right]} & \begin{array}{l}
\text { the mid vowel [o] is banned under stress in plural } \\
\text { forms of neuter nouns }
\end{array}
\end{array}
$$

I illustrate the crucial rankings in a series of tableaux. For all four wellformedness constraints above, one example is sufficient to illustrate the relative ranking of the morphologically specific constraints in the hierarchy. For adjectives, the example is presented as an integrated tableau for the masculine and feminine forms sek and seakə 'dry'

\footnotetext{
7. Potential outcomes of lil and lul with two lal particles are the mid lax vowels [c] and [o]. These are non-optimal because of high ranking markedness constraints against lax vowels in Romanian.
} 


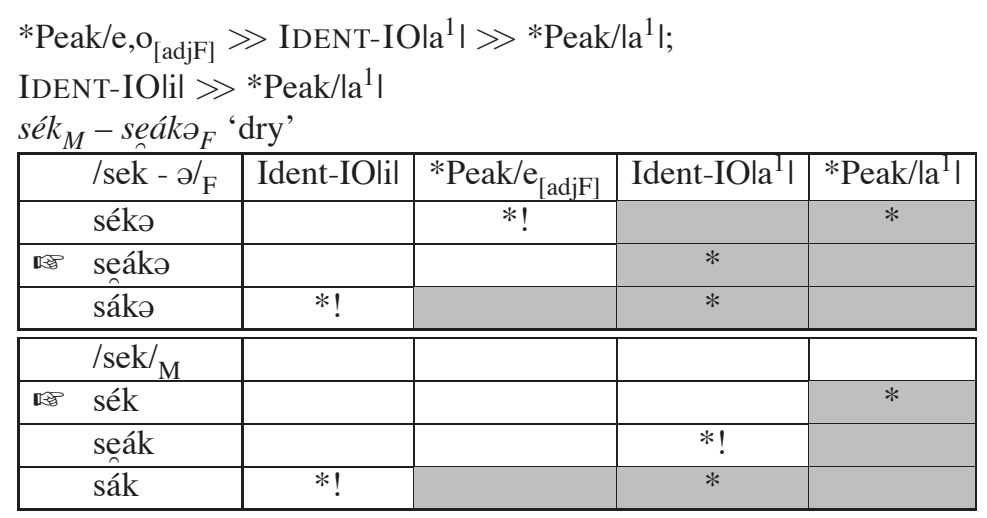

In the feminine form, the diphthong is selected as the preferred vowel under stress. The diphthong and [a] both satisfy the morphological *Peak/e constraint, but [a] does not preserve palatality. The masculine form is not subject to the morphologically specific *Peak constraint. The first candidate, faithful to the input, is the winner. Both masculine and feminine forms show evidence for the low ranking of $*$ Peak $/ \mathrm{a}^{1}$ l.

The integrated tableau above for the pair $s k_{M}-$ seak $_{F}$ shows that the interaction with morphology is captured by the morphologically specific constraint ${ }^{*}$ Peak $/\left.\mathrm{la}^{1}\right|_{[\mathrm{adj}}$, as well as by the ranking of IDENT-IOla ${ }^{1} \mid$ above $*$ Peak/la ${ }^{1} \mid$. Thus IDENT-IOla ${ }^{1} \mid$ intervenes between the specific and the general constraints.

In the case of e-ea alternations, another important ranking which has to be determined involves IDENT-StSf. This will be illustrated again in an integrated tableau for the plural forms of the same adjective 'dry'. The feminine and masculine forms happen to be identical, both surfacing as set ${ }^{j}$. The following tableau thus illustrates the relative ranking of IDENT-StSflal.

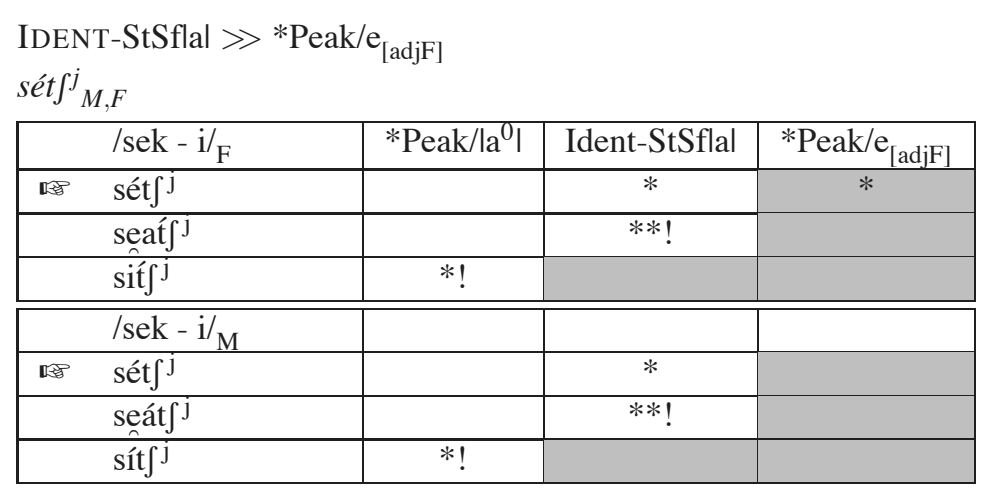

Both the masculine and the feminine plural forms are subject to metaphony. This is captured by the ranking of IDENT-StSflal above the morphologically 
specific constraint, and thus also above the general *Peak constraint. In the feminine form, the second candidate satisfies the morphological constraint by containing a low diphthong under stress, but is rejected because it has one lal particle too many relative to the suffix vowel. The third candidate best matches the height of the suffix vowel, but is eliminated by the higher ranking $*$ Peak $/ \mathrm{l}^{0} \mathrm{I}$. Similarly in the masculine form the winner is determined by the interaction of *Peak/la $\mathrm{a}^{0} \mathrm{I}$ and IDENT-StSf. The same mid vowel [e] is optimal. The only difference is that [e] in the masculine form does not violate the morphological *Peak constraint, only the lower ranked general one.

The effect of IDENT-StSflal is illustrated in the integrated tableau of two feminine plural forms, the adjectives bete 'drunk' and drepte 'straight'. They have different underlying representations, but they are predicted by the same constraint ranking.

\begin{tabular}{|c|c|c|c|c|}
\hline & /beát - e/F & IDENT-StSflal & ${ }^{*} \mathrm{Peak} / \mathrm{e}_{[\mathrm{adj} F]}$ & IDENT-IOla ${ }^{1} \mid$ \\
\hline & beáte & $* !$ & & \\
\hline \multirow[t]{3}{*}{ 承 } & béte & & * & \\
\hline & /drept - e/F & & & \\
\hline & dreápte & $* !$ & & * \\
\hline 吗 & drépte & & * & \\
\hline
\end{tabular}

As in (60), the diphthong best satisfies the morphological *Peak constraint, but violates higher ranking IDENT-StSf because of the additional lal particle. The second candidate containing [e] is thus preferred in both cases. Vowel height matches in the stem and the suffix.

In addition to the morphologically specific well-formedness constraints, I proposed two specific faithfulness constraints.

(62) Morphologically specific faithfulness constraints

$$
\begin{array}{ll}
\text { IDENT-StSfla }\left.^{0}\right|_{[\text {nounF] }} & \begin{array}{l}
\text { In feminine nouns the stressed vowel of the } \\
\text { stem must match the aperture of the suffix } \\
\text { high vowel. }
\end{array} \\
\text { IDENT-IO[ea] }]_{[\text {neuter] }} & \begin{array}{l}
\text { In neuter nouns the diphthong [ea] of an input } \\
\text { form must surface in the output. }
\end{array}
\end{array}
$$

In the case of the a-ə alternation, the morphological constraint I propose is a specific instantiation of IDENT-StSflal, outranking the general constraint. The constraint requires feminine nouns to undergo metaphony before a high vowel suffix. It is therefore indexed as [nounF], affecting all the lexical items belonging to the morphological class of feminine nouns. The fact that non-feminine nouns do not undergo metaphony is predicted by the intermediate ranking of 
faithfulness to [a] between the specific and the general IDENT-StSf constraints: IDENT-StSfla $\left.{ }^{0}\right|_{\text {nounF] }} \gg$ IDENT-IO[a] $\gg$ IDENT-StSflal. The constraint subhierarchy is illustrated below, in an integrated tableau containing a feminine plural form (karte $-k^{2}$ rts $^{j}$ 'book') and a masculine one (brad $-\mathrm{braz}^{j}$ 'fir tree').

\begin{tabular}{|c|c|c|c|c|c|}
\hline & $/$ kart $-\mathrm{i} / \mathrm{F}$ & ${ }^{*}$ Peak $/ a^{0}$ & $\begin{array}{c}\text { IDENT- } \\
\text { StSfla }\left.^{0}\right|_{[\text {nounF] }}\end{array}$ & $\begin{array}{l}\text { IDENT- } \\
\text { IO[a] }\end{array}$ & $\begin{array}{l}\text { IDENT- } \\
\text { StSfla0 }\end{array}$ \\
\hline & karts $^{j}$ & & $* * !$ & & $* *$ \\
\hline 㵵 & kərts $^{j}$ & & * & $*$ & * \\
\hline & kirts $^{j}$ & $* !$ & & * & \\
\hline & /brad - i/M & & & & \\
\hline 酌要 & braz $^{j}$ & & & & ** \\
\hline & brəz $^{j}$ & & & $* !$ & * \\
\hline & briz $^{j}$ & $* !$ & & & \\
\hline
\end{tabular}

The feminine plural form $k$ rarts ${ }^{j}$ is selected by the morphologically specific IDENT-StSf constraint outranking IDENT-IO[a]. The first candidate is faithful to the input low vowel /a/, but this vowel has two aperture particles more than the suffix vowel. The second candidate, $k ə r t s^{j}$, has only one additional aperture particle, and thus incurs only one violation of IDENT-StSfla ${ }^{0}$.

The masculine plural form is not affected by the morphologically specific IDENT-StSf constraint. In this case, the ranking of IDENT-IO[a] above the general IDENT-StSf selects the first candidate, in which the low vowel is maintained in the stem.

As noted earlier, [á] does not undergo metaphony before the - $e$ suffix. Thus, the [a] in the plural form in the pair kásə - káse 'house' is predicted simply by IDENT-IO[a] outranking the general IDENT-StSf.

The constraint subhierarchy illustrated in tableau (64) also accounts for the absence of [oa] in feminine plural forms which take the plural marker ${ }^{j}$ (e.g., poart - ports $^{j}$ 'gate', groap - grop $^{j}$ 'ditch', boalə - bol ${ }^{j}$ 'illness'). The ranking IDENT-StSfla $\left.{ }^{0}\right|_{[\text {nounF] }} \gg$ IDENT-IO[oa] predicts that a non-low vowel surfaces in the stem, in a feminine noun. Masculine nouns such as oaspete (pl. oaspets ${ }^{j}$ ) are not affected by the morphological faithfulness constraint. The ranking IDENT-IO[oa] $\gg$ IDENT-StSflal predicts that the diphthong is maintained in the plural forms of masculine nouns.

The constraint ranking captures directly the generalization with which I started out, namely that the diphthongs and [a] pattern together as low vowels in Romanian. With respect to metaphony, the diphthong [oa] patterns with [a] rather than with the other diphthong, [ea]. The first two are only affected 
by metaphony when they occur in feminine nouns. They obey the morphologically specific IDENT-StSfla ${ }^{0}$ I constraint. Also unlike [ena], [oa] and [a] are not affected by the metaphony triggered by $-e$. This suggests that faithfulness to [a] and [oa] outranks faithfulness to [ea]. I illustrate how the behavior of [oa] is parallel to that of $[\mathrm{a}]$ in the following integrated tableau, also containing a feminine and a masculine plural form (ports ${ }^{j}$ 'gates' vs. oaspets ${ }^{j}$ 'guests'). No additional constraints are needed. The crucial subhierarchy is still the specific IDENT-StSf dominating the general one, with faithfulness to [oa] ranked between them.

\begin{tabular}{|c|c|c|c|c|c|}
\hline \multicolumn{2}{|r|}{ /poart - i/ $/ F$} & ${ }^{*} \mathrm{Peak} / \mathrm{a}^{0}$ & $\begin{array}{c}\text { IDENT- } \\
\text { StSfla }\left.^{0}\right|_{\text {[nounF] }}\end{array}$ & $\begin{array}{l}\text { IDENT- } \\
\text { IO[oa] }\end{array}$ & $\begin{array}{l}\text { IDENT- } \\
\text { StSfla }{ }^{0}\end{array}$ \\
\hline & poarts $^{j}$ & & $* * !$ & & $* *$ \\
\hline 酌等 & ports $^{j}$ & & * & * & * \\
\hline & purts $^{j}$ & $* !$ & & $*$ & \\
\hline & /oaspet - $\mathrm{i} / \mathrm{\Lambda}$ & & & & \\
\hline 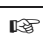 & oaspets ${ }^{j}$ & & & & ** \\
\hline & ospets ${ }^{j}$ & & & $* !$ & * \\
\hline & uspets $^{j}$ & $* !$ & & & \\
\hline
\end{tabular}

If we take a close look at the formulation of the morphologically specific IDENT-StSf, it appears that it is in a way doubly restricted: once to the morphologically defined class of feminine nouns, as reflected in the indexation, and once to suffixes containing high vowels. I assume that the ability of languages to develop morphologically specific constraints is universal, as is the ability to develop lexically specific faithfulness constraints applying to non-native lexical items (cf. Itô and Mester 1999). What is determined on a language-specific basis is the indexation, the class of items which obeys the specific constraints, and which can be morphologically or lexically defined. Under this view, a constraint such as IDENT-StSfla ${ }_{[\text {nounF] }}$ is a fairly complex constraint, since in addition to the indexation, a speaker also needs to figure out that the required faithfulness is restricted to the absence of an aperture particle $\left(\left|\mathrm{a}^{0}\right|\right)$. The existence of such a constraint would be supported by independent evidence for separate general IDENT-StSf constraints, one for $\mathrm{la}^{0} \mathrm{l}$ and one for $\mathrm{la}^{1} \mathrm{l}$, relatively ranked with respect to one another. The resulting grammar would then be a simpler one.

I did find such evidence in the case of plural neuter nouns containing underlying $/ \mathrm{o} /$. We saw that before the plural marker $-e$, the diphthong [oa] surfaces, as in kovor - kovoare 'carpet'. This is predicted by the ranking of *Peak $/ \mathrm{o}_{[\text {neuter] }}$ above IDENT-StSflal. Neuter nouns can also take the plural marker - $u r^{j}$. In this case, $[\mathrm{o}]$ surfaces, as predicted by IDENT-StSflal outranking $*$ Peak $/ \mathrm{o}_{[\text {neuter] }}$. The 
difference between the two cases of metaphony is that the first one is triggered by a mid vowel ([e]), and the second one by a high vowel. The two forms show evidence for the subhierarchy IDENT-StSfla ${ }^{0} \mathrm{I} \gg *$ Peak $/ \mathrm{o}_{[\text {neuter] }} \gg$ IDENTStSfla ${ }^{1}$. The clearest illustration of the relevant subhierarchy involves the plural forms rapoarte 'reports', and raportur ' 'relationships', both based on an identical singular neuter form raport.

$$
\text { IDENT-StSfla }{ }^{0} \mid \gg * \text { Peak } / \mathrm{o}_{[\text {neuter] }} \gg \text { IDENT-StSfla }{ }^{1} \mid
$$

\begin{tabular}{|c|c|c|c|c|}
\hline & /raport $-\mathrm{e} /{ }_{N}$ & IDENT-StSfla $^{0}$ & ${ }^{* P e a k} / \mathrm{O}_{\text {[neuter] }}$ & IDENT-StSfla $^{1}$ | \\
\hline & raporte & & $* !$ & \\
\hline & rapoarte & & & * \\
\hline & /raport - uri/s & & & \\
\hline 喁 & raportur $^{\mathrm{j}}$ & $*$ & * & \\
\hline & rapoartur $^{j}$ & $* * !$ & & \\
\hline
\end{tabular}

In the presence of the plural marker -e, the ranking illustrated in (65) predicts the surface occurrence of the diphthong, since the morphological *Peak/o constraint outranks IDENT-StSfla ${ }^{1}$. But when the plural marker is $-u r^{j}$, the same ranking predicts the occurrence of the mid vowel $[0]$, since $*$ Peak $/ \mathrm{o}_{[\text {neuter] }}$ is dominated by IDENT-StSfla ${ }^{0}$.

The second and last morphologically specific faithfulness constraint requires the diphthong [e्na] of the input to surface in the plural form of neuter nouns, regardless of the plural marker. The relevant constraint interactions are illustrated below, in a tableau for the neuter plural form dealur ' 'hills' and the feminine plural form trebur $^{j}$ 'tasks'.

\begin{tabular}{|c|c|c|c|c|}
\hline \multicolumn{2}{|r|}{ /deal - uri/ $/ \mathrm{N}$} & $\left.\operatorname{IDENT}_{[\mathrm{e} a}\right]_{[\text {neuter] }}$ & IDENT-StSfla $^{0}$ & *Peak/e \\
\hline & deálur $^{j}$ & & $* *$ & \\
\hline & délur $^{j}$ & $* !$ & & $*$ \\
\hline & /treab - uri// & & & \\
\hline & treábur $^{j}$ & & $* * !$ & \\
\hline 网 & trébur $^{j}$ & & $*$ & * \\
\hline
\end{tabular}

The two examples above show that the morphologically specific faithfulness constraint outranks IDENT-StSf. The winning candidate of the first form, the neuter noun, is the one containing the diphthong. It satisfies the high ranking specific faithfulness constraint by preserving the diphthong. In the case of the feminine noun, the two aperture particles of the diphthong incur two violations of IDENT-StSfla ${ }^{0}$, as opposed to only one violation by the mid vowel of the second candidate. The second candidate violates *Peak/e by allowing [e] to 
surface under stress, but this constraint is lower ranked. The second candidate is therefore selected.

The constraint subhierarchy involving the morphologized and general IDENTStSf constraints is put together below.

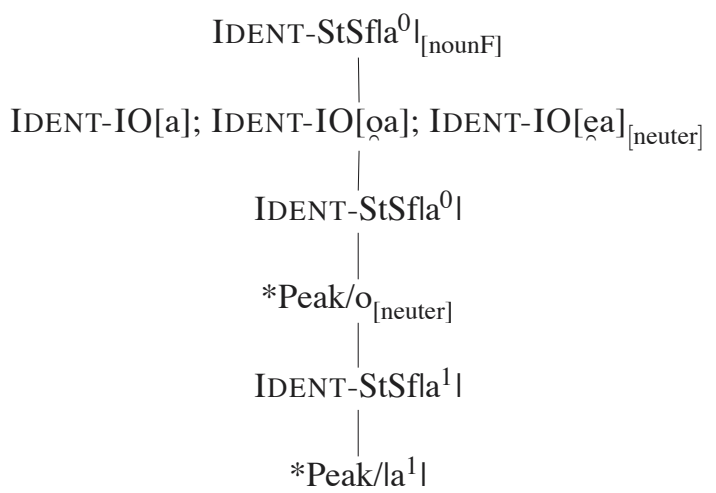

\section{Discussion and conclusions}

Specific constraints outranking general ones have previously been proposed in the literature as a way of dealing with lexical exceptions. For example, lexically specific constraints have been proposed by Pater (2000) for a number of English secondary stress patterns, Itô and Mester (1999) for the Japanese lexicon, Wetzels (1999) for French h-aspiré, Hammond (1995) for exceptional stress in Spanish. Lexically specific constraints are a preferred alternative to lexical marking and to constraint domains (co-grammars), proposed, for example, by Itô and Mester (1995a, b). The same exceptional patterns that can be captured by marking or diacritics on individual lexical items can be captured by the assumption that a given constraint can operate more than once in a grammar, in two different places in the hierarchy. The higher ranked constraint affects only a specific subset of lexical items, which, in Itô and Mester's (1999) model, is achieved formally by constraint indexation. The replication of constraints through specific versions is apparently unrestricted, and Itô and Mester express concern about the power of lexically specific constraints. Potentially any constraint can expand into one or any number of specific versions. In an attempt to restrict the range of predicted phenomena, Itô and Mester argue that only faithfulness constraints can have lexically specific versions. Pater (2000), however, shows that a lexically specific structural constraint is crucially needed for a successful analysis of the English stress system. Most of the specific constraints I propose are also structural, only two are faithfulness constraints. 
I would therefore like to consider for a moment the possibility of an alternative analysis of Romanian diphthongization, in which faithfulness constraints rather than structural ones are morphologized. One possibility, as suggested by one of the reviewers, is the morphological indexation of INTEGRITY. For example, the fact that input mid vowels /e/ and /o/ surface under stress in masculine adjectival forms (e.g., sék 'dry') can be captured by the existence of a constraint INTEGRITY $[\mathrm{e}, \mathrm{o}]_{[\mathrm{[dj} M]}$ outranking the general INTEGRITY constraint. The diphthongs are selected in feminine forms (e.g., seákə 'dry'), therefore *Peak/e,o must rank in-between the specific and the general constraints:

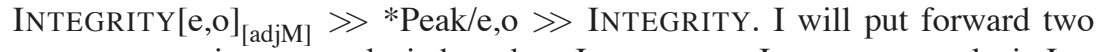
arguments against an analysis based on INTEGRITY. In my own analysis INTEGRITY is simply assumed to rank very low, so we do not see it interact with other constraints. This is because INTEGRITY refers crucially to the diphthongs, to their segmental structure involving a split root node, but has nothing to say about the a-o alternation, for example, which is simply a vowel height alternation. An analysis based on morphologized INTEGRITY would then lose the generalization that diphthongization is part of a broader phenomenon involving mid and low vowel alternations, and would consequently fail to provide a unified account of its different instantiations. In addition, morphologized INTEGRITY constraints fail to capture one other important generalization, namely that the diphthongs behave as morphological markers. Morphologized *Peak constraints single out the diphthongs as morphological markers, but morphologized INTEGRITY constraints instead single out the mid vowels or the absence of diphthongs as marking morphological categories. We have seen, however, that the distribution of diphthongs is in general more limited than that of mid vowels. This means that many more morphologized INTEGRITY constraints are needed in the grammar than morphologized *Peak constraints. If indexation singles out marked behavior, then the mid vowels emerge as marked instead of the diphthongs. As such, the role of the diphthongs in the grammar is much less intuitive, and it is not clear why such constraints would develop. It is my understanding that lexical constraint indexation, for example, captures marked behavior, such as lexical exceptions or non-native phonology. It makes sense that morphological indexation should then also capture phonological exceptions which, precisely by virtue of being exceptions, are morphological markers.

Another possible analysis featuring morphologized faithfulness constraints can make use of positional faithfulness. Beckman's (1997) IDENT- $\sigma(\mathrm{F})$ is a good alternative, in that it avoids the first problem described above, by allowing a unified analysis of diphthongization and mid-low vowel alternations. The second counter-argument, though, is still valid. A possible positional faithfulness analysis would involve the subhierarchy IDENT- $\left.\left.\sigma\right|_{\text {a }}\right|_{[\operatorname{adjM}]} \gg *$ Peak/e,o $\gg$ IDENT- $\sigma \mid$ al. In this case the morphologized constraints are faithfulness 
constraints that require preservation of the number of aperture particles. The relevant alternations can be accounted for, but the morphologized faithfulness constraints again single out the absence rather than the presence of the diphthongs in the output as marking a morphological category. This is counterintuitive, given the basic generalization laid out at the outset. Both alternatives are particularly problematic in the verb system, where the distribution of the diphthongs is much more limited than in nouns and adjectives. This situation therefore requires a very large number of morphologically indexed faithfulness constraints to account for all the verb forms which do not contain diphthongs under stress.

To return to Itô and Mester's (1999) model, they claim that the restriction of constraint replication to faithfulness constraints is a general property of grammars, not just of the core-periphery model of the lexicon. I have shown, however, that morphologically specific markedness constraints are also needed. A final decision on this question clearly requires more empirical evidence, specifically from in-depth studies of individual linguistic systems in all their complexity, considering both regular and exceptional patterns.

The main trade-off here seems to be between an analysis which directly captures the initial generalizations, and one which "protects" the theory by maintaining the exclusion of indexed markedness constraints. I have opted for the former, apparently at the risk of weakening the theory as developed so far. I maintain, however, that not enough evidence is available at this point as to whether indexed markedness constraints can be entirely dispensed with. The status of exceptions, lexical or morphological, has not been sufficiently studied so far in the framework of Optimality Theory. I believe that there is a difference between lexically restricted and morphologically restricted patterns, in the sense that the latter are less of an exception than the former. In terms of learnability morphologically restricted patterns may be easier to handle. Indexation to a morphological category is not as taxing as indexation to a subset of lexical items, which still have to be learned individually as exceptions. What we may find by looking at more languages is that morphologically specific markedness and faithfulness constraints are both needed, while pure lexical exceptions can be handled by specific faithfulness constraints only. This is a theoretical issue which certainly deserves attention.

I have discussed so far the morphologically specific constraints, but recall that non-native adjectives and verbs do not show the alternation between mid vowels and diphthongs. The only morphologized alternation which is present throughout the lexicon is the $\mathrm{o}-\mathrm{O}$ a alternation found in neuter nouns, between the singular and the plural forms. Both native and non-native words thus satisfy *Peak/o ${ }_{[\text {neuter] }}$ : kuptor - kuptoare 'oven', klasor - klasoare 'file'. The grammar must therefore also contain a lexically indexed faithfulness constraint which requires identity in vowel height between input and output in non-native items: 
IDENT-IOla $\left.^{1}\right|_{[\text {non-nat] }}$. The ranking $*$ Peak $/ \mathrm{o}_{\text {[neuter] }} \gg$ IDENT-IOla $\left.^{1}\right|_{[\text {non-nat] }} \gg$ *Peak/la $\left.{ }^{1}\right|_{[\text {morph }]}$ captures the fact that all morphologized *Peak constraints except for $*$ Peak $/ \mathrm{O}_{[\text {neuter] }}$ are violated by non-native lexical items. The final full constraint ranking in (68) is proposed to account for the mid-low vowel alternations at the current stage of Romanian.

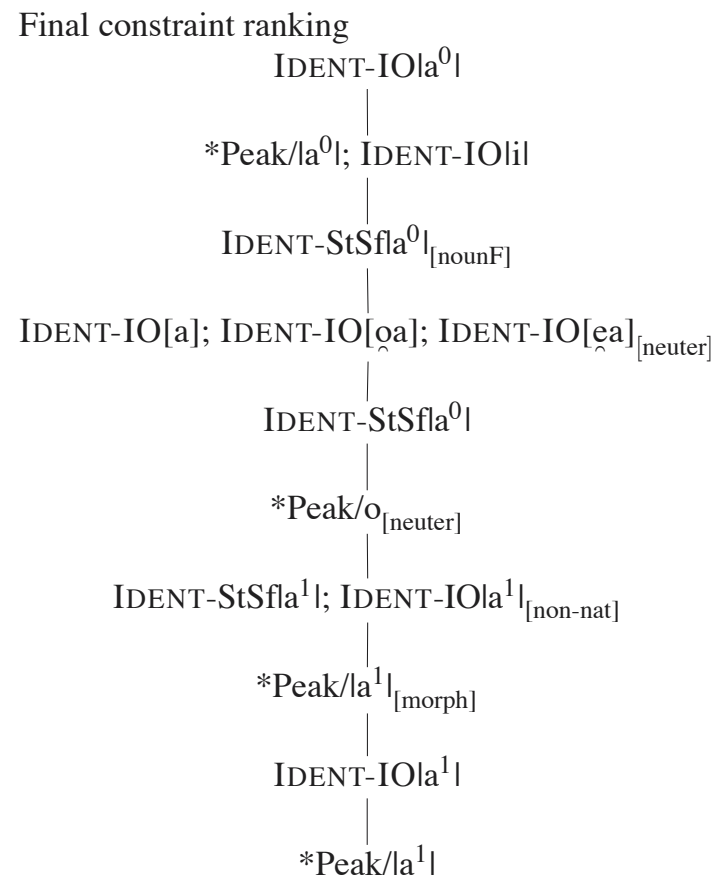

I proposed in this paper an analysis of mid vowel-diphthong alternations in Romanian, which I treat as vowel lowering under stress. The analysis relies on the interaction of the *Peak/V constraints of the Peak Prominence scale with two metaphony constraints which I define as instances of faithfulness between the vowel of the stem and that of the suffix. This approach also reveals the typological relation of Romanian to well-attested systems in which stress is sensitive to vowel height (or sonority). The analysis I propose also accounts for the fact that the alternations are morphologically conditioned, but phonologically restricted. In this respect the facts discussed here provide evidence for the existence of specific and general constraints in a grammar. Both structural and faithfulness constraints are found to have higher ranking, morphologically specific instantiations. 


\section{References}

Agard, Frederick B. (1958). Structural sketch of Rumanian. Language 34/3. Language Monograph 26. Linguistic Society of America, Baltimore: Waverly Press.

- (1984). A Course in Romance Linguistics. Washington: Georgetown University Press.

Avram, Andrei (1991). Semivocalele, semiconsoanele și pseudovocalele în română. Studii sci cercetări lingvistice 6: 193-205.

Baković, Eric (2000). Harmony, dominance and control. PhD dissertation, Rutgers University.

Beckman, Jill N. (1998). Positional faithfulness. Ph.D dissertation, University of Massachusetts, Amherst.

Chitoran, Ioana (1996). Prominence vs. rhythm: The predictability of stress in Romanian. In Grammatical Theory and Romance Languages, Karen Zagona (ed.), 47-58. Amsterdam/ Philadelphia: John Benjamins.

- (1997). The phonology and morphology of Romanian glides and diphthongs: A constraintbased approach. PhD dissertation, Cornell University.

- (2001). The Phonology of Romanian: A Constraint-Based Approach. Berlin: Mouton de Gruyter.

Goad, Heather (1992). On the configuration of height features. PhD dissertation, University of Southern California.

Golopenția-Eretescu, Sanda (1967). Vowel alternations in transformational grammar. In Phonologie der Gegenwart, Josef Hamm (ed.), 134-141. Graz-Wien-Köln: Hermann Bölhaus Nachf.

Graur, Alexandru and Alexandru Rosetti (1938). Esquisse d'une phonologie du roumain. Bulletin Linguistique 6: 5-29.

Hammond, Michael (1995). There is no lexicon! Coyote Papers: Working Papers in Linguistics, vol. 10, University of Arizona, 2000 (1995 version available on ROA)

Harris, James W. (1983). Syllable Structure and Stress in Spanish: A Nonlinear Analysis. Cambridge, London: MIT Press.

Hualde, Jose-Ignacio (1989). Vowel-harmony systems in Spain. Linguistics 27: 773-805.

- (1992). Catalan. London: Routledge.

Iordan, Iorgu (1921). Diftongarea lui /e/ ș /o/ accentuați în pozitiile a, e. Iași.

Itô, Junko and Armin Mester (1995a). Japanese Phonology. In The Handbook of Phonological Theory, John Goldsmith (ed.), 817-838. Cambridge, MA and Oxford: Blackwell.

- (1995b). The core-periphery structure of the lexicon and constraints on re-ranking. In Papers in Optimality Theory, University of Massachusetts Occasional Papers 18: 181-209.

- (1999). The phonological lexicon. In The Handbook of Japanese Linguistics, N. Tsujimura (ed.), 62-100. Malden, MA and Oxford: Blackwell.

Kaye, Jonathan D. and Jean Lowenstamm (1984). De la syllabicité. In La forme sonore du langage. François Dell, D. Hirst and J-R. Vergnaud (eds.), 123-159. Paris: Hermann.

Kenstowicz, Michael (1994). Sonority-driven stress. Ms., MIT.

Lombard, Alf (1974). La langue roumaine. Paris: Klincksieck.

Maiden, Martin (1991). Interactive Morphonology: Metaphony in Italy. London: Routledge.

Martinet, André (1962). Review of A. Rosetti (ed.), Recherches sur les diphtongues Roumaines. Bulletin de la société de linguistique de Paris 57/2: 119-122.

McCarthy, John and Alan Prince (1995). Faithfulness and reduplicative identity. Papers in Optimality Theory, University of Massachusetts Occasional Papers 18: 249-384.

Morin, Yves-Charles (1976). Phonological tensions in French. In Current Studies in Romance Linguistics, F. Hensey and M. Lujàn (eds.), 37-49. Washington DC: Georgetown University Press.

Pardess, David F. (1990). From Latin to Romanian: Phonological rules. Ph.D. Dissertation, UCLA. Parkinson, Frederick B. (1996). The representation of vowel height in phonology. Ph.D. dissertation, The Ohio State University. 
Pater, Joe (2000). Non-uniformity in English secondary stress: The role of ranked and lexically specific constraints. Phonology 17 (2): 237-274.

Prince, Alan and Paul Smolensky (1993). Optimality theory: Constraint interaction in generative grammar. Rutgers University Center for Cognitive Science Technical Report 2.

Rialland, Annie (1994). The phonology and phonetics of extrasyllabicity in French. In Papers in Laboratory Phonology III. Phonological Structure and Phonetic Form, Patricia A. Keating (ed.), 136-159. Cambridge: Cambridge University Press.

Rosetti, Alexandru (1958). Slavo-romanica. Sur la construction du système vocalique en roumain. Romanoslavica 1: 27-30.

- (1959). Recherches sur les diphtongues roumaines. Bucharest: Editura Academiei RPR/ Copenhagen: Munksgard.

- (1976). Asupra monoftongării diftongului ea în limba română. Studii și cercetări lingvistice 27: 423-424.

- (1981). Le sort du latin /i/ accentué en roumain. Revue roumaine de linguistique 26: 135.

Ruhlen, Merritt (1973). Rumanian phonology. Ph.D. dissertation, Stanford University.

Sala, Marius (1976). Contributions à la phonétique historique du roumain. Bucharest: Editura Academiei/Paris: Klincksieck.

Schane, Sanford A. (1984). The fundamentals of particle phonology. Phonology 1: 129-155.

- (1995). Diphthongization in particle phonology. In The Handbook of Phonological Theory, J. Goldsmith (ed.), 586-608. Cambridge, MA and Oxford: Blackwell.

Tranel, Bernard (1992). The Sounds of French: An Introduction. Cambridge: Cambridge University Press.

Vasiliu, Emanuel (1965). Fonologia limbii române. București: Editura Stiintịifăă.

- (1968). Fonologia istorică a dialectelor daco-române. Bucharest: Editura Academiei RSR.

- (1990). Semivocalele românești $e, i$ și problema non-unicitătii descrierilor fonologice. Studii si cercetări lingvistice 41 (3): 253-257.

Wetzels, Leo (1991). Contrastive and allophonic properties of Brazilian-Portuguese vowels. In New Analyses in Romance Linguistics, D. Wanner and D.A. Kibbee (eds.), 77-99. Amsterdam: John Benjamins.

- (1999). Handout from the Potsdam summer school in linguistics: Topics in the phonology of Romance languages. 